\title{
PRECHODY CEZ DOLNÝ A STREDNÝ TOK RIEKY VÁH VO VRCHOLNOM A NESKOROM STREDOVEKU V KONTEXTE PÍSOMNÝCH A HMOTNÝCH PRAMEŇOV
}

\author{
PETER IVANIČ - MARTIN HUSÁR
}

\begin{abstract}
Abstrakt: Autori príspevku sa pri spracovani témy prechodov cez rieku Váh od Trenčína po Komárno vo vrcholnom a neskorom stredoveku opierali najmä o archeologické a pisomné pramene, no v neposlednom rade aj o kartografické a obrazové pramene z mladšich období. Prechody cez rieky (brody, prievozy a mosty) zohrávali v sledovanom obdobi dôležitú úlohu v rámci vtedajšej cestnej siete. Zo zhodnotenia celého skúmaného územia vyplýva, že väčšina lokalit uvedených v primárnych písomných prameňoch je doložená i lokalitami s vodnými nálezmi. Vodné nálezy z povodia Váhu smerom na sever od Šale boli zastúpené skoro výhradne zbraňami - väčšinou bodno-sečnými. Tieto zbrane mohli byt’ skôr intencionálne deponované. Na druhej strane vodné nálezy od Šale po obec Neded priniesli predmety s rôznorodou skladbou, čo môžeme spojit’ pravdepodobnejšie s dopravou, obchodom alebo náhodným odplavením predmetu.
\end{abstract}

Kl'účové slová: prechody - Váh - vrcholný stredovek - neskorý stredovek - písomné pramene - archeologické pramene.

Crossings over the lower and central reaches of the River Váh in the high and late Middle Ages in the context of written and material sources

Abstract: In their contribution on the subject of crossings over the River Váh between Trenčin and Komárno in the high and late Middle Ages, the authors predominantly employed archaeological and written sources, as well as cartographic and pictorial sources from more recent periods. River crossings (fords, ferries and bridges) played an important part in the observed period in the transportation network. The analysis of the investigated territory showed that the majority of locations listed in primary written sources were also sites with water finds. Water finds from the Váh catchment area to the north of Šala almost exclusively comprised weapons, mostly stabbing and cutting ones. The weapons might have been deposited in the river intentionally. In contrast, water finds from the area between Šala and the village of Neded included miscellaneous objects that might be associated with transport, trade or the accidental washing away of these objects.

Key words: crossings - River Váh - high Middle Ages - late Middle Ages - written sources - archaeological sources.

\section{Úvod}

Časový záber nášho príspevku zahŕňa obdobie vrcholného a neskorého stredoveku, ktoré je v našom ponímaní od druhej polovice 11. storočia do prvej polovice 16. storočia, pričom berieme do úvahy aj nálezy, ktoré sa nedajú na polstoročie či precíznejšie datovat', teda aj z priebehu 11. a 16. storočia. Vychádzame pri tom z nedávno publikovaných štúdíi týkajúcich sa periodizácie stredoveku na Slovensku. ${ }^{1}$ Geografické vymedzenie nami skúmaného územia je od katastrálnych území súčasného Trenčína smerom dolu Váhom, cez katastrálne územia obcí popri koryte Váhu až po katastrálne územia Komárna. ${ }^{2}$

Prechody cez rieky (brody, prievozy a mosty) zohrávali v období stredoveku dôležitú úlohu v rámci vtedajšej cestnej siete. Váh je s dížkou $403 \mathrm{~km}$ a plochou povodia $19696 \mathrm{~km}^{2}$ najväčšou riekou na území Slovenska a odvodňuje prakticky $40 \%$ územia štátu (Pišút-Procházka-Matečný-Bandura 2016, 7). V stredoveku bola spomenutá už v interpolovanej zakladacej listine

\footnotetext{
1 Slovenský archeológ Jozef Zábojník (2010, 213-214) dáva koniec včasného stredoveku do začiatku 11. storočia, kedy môžeme hovorit’ už o počiatočnej fáze vývoja Uhorského královstva. Vrcholný stredovek d’alší slovenský archeológ Igor Hrubec (1980, 230-231) na Slovensku zasadil do 11. až 14. storočia a neskorý do 15. až prvej polovice 16. storočia. Medzníkom bol teda rok 1400 a koniec neskorého stredoveku sa nachádzal v polovici 16. storočia. V domácej i zahraničnej historickej spisbe sa dnes predel medzi vrcholným a neskorým stredovekom kladie už do polovice 13. storočia (Múcska-Daniš-Ševčíková 2006, 10-12) alebo k roku 1300 a koniec neskorého stredoveku k začiatku 16. storočia (Múcska-Daniš-Ševčíková 2006, 11). Začiatok vrcholného stredoveku sa v tejto literatúre umiestňuje do polovice 11. storočia (Múcska-Daniš-Ševčíková 2006, 10).

2 V kontexte delenia povodia Váhu a jeho prítokov Slovenským vodohospodárskym podnikom, š p., sledujeme v našom článku tým pádom koryto Váhu v rámci Váhu - Vnútorných vôd, Dolného Váhu a väčšej časti Stredného Váhu II (Stavy a prietoky na vodných tokoch).
} 
svätobeňadického opátstva, ktorá sa hlási k roku 1075. Hodnoverne je však doložená až v rokoch 1111 ako flumen Vvaga a 1113 ako aqua Vvac (Varsik 1990, 20).

Cestujúci mohli Váh prekonávat’ prostredníctvom prievozov/kômp (lat. sg. ponto) alebo potrebovali nájst' vhodné miesto, na ktorom bola hladina rieky nízka a prúd nie až taký silný. V dokumentoch sa brody objavujú pod latinským pojmom vadum pri metáciách jednotlivých území. Pod termínom brod nemožno chápat'v stredoveku iba spevnený a udržovaný prechod. Pri väčších tokoch ako je Váh bol prechod obmedzený len na určité miesta. Ak sa brod využíval frekventovane a dlhšiu dobu, tak slúžil tiež ako orientačný bod a výrazný krajinný prvok (Klimek 2014, 78). Pre prístav sa používal v písomnostiach latinský termín portus. Vznikol z latinského slovesa portare - niest', viest', dovážat' alebo odvážat'. Prístavy, ktoré mohli síce slúžit' aj ako miesta prechodu ciest cez vodné toky, mohli ale figurovat' aj ako ordinárne prístavy a nezriedka i ako trhové miesta. V stredovekých listinách sa objavuje pri lokalitách v blízkosti riek aj informácia o poplatkoch označovaných latinsky ako naulum alebo navigium. Niekedy ide o poplatok za tovar prevážaný lod’ou, ale väčšinou nám tieto termíny indikujú existenciu prievozu. V známom spise Ianua linguarium reseta od Jána Ámosa Komenského sa konkrétne uvádza, že kde nie je brod, tak sa prechádza na tráme nazývanom trajekt (pontone trajiciunt, diciturque Trajectus), ale prievozníkovi sa platí poplatok - naulum. V diele Friderica Martina s názvom Singularia iuris je zmienka, že naulum alebo portarium je termín pre tovar prevážaný cez rieku (Klimek 2014, 83-84). Brody boli tak ako prístavy z praktického hladiska vhodné na výber mýta na ceste, pretože $\mathrm{v}$ danom priestore sa dali len t’ažko obíst'. Tam, kde to charakter okolitého prostredia dovol'oval, boli postavené mosty (lat. sg. pons). Z obdobia stredoveku je len niekol'ko zmienok o mostoch na území dnešného Slovenska. Tieto sa vd’aka polohe a pohodlnejšiemu i bezpečnejšiemu prechodu stali typickým mýtnym miestom.

Na západnom a severozápadnom Slovensku významnú komunikačnú úlohu plnila Považská cesta, ktorá viedla v stredoveku od Komárna popri Váhu cez Šintavu, Hlohovec, Trenčín do Žiliny a odtial' d’alej do Pol'ska a na Spiš (Fridrichová 2017, 70-76). Na ňu sa pripájali viaceré komunikácie, ktoré viedli z iných regiónov (napr. Morava, Ponitrie). Cez dolné Považie viedla aj známa Česká cesta. ${ }^{3}$ Na jej trase boli aj Sered' a Šintava. V Seredi vznikli i vd’aka tomu významné trhy s obilím a dobytkom (Labuda 2016, 65). Na Považí existovalo niekol'ko prechodov cez rieku Váh, ku ktorým sú zachované priame doklady v písomných dokumentoch.

Popri písomných, ale aj obrazových (veduty, panorámy miest) a kartografických (najmä Prvé vojenské mapovanie Uhorska v rokoch 1782-1785) prameňoch, tvoria archeologické pramene významnú kategóriu nálezov k riešeniu preberanej témy. Pre náš článok sme si z nich vybrali na posúdenie vodné nálezy z koryta Váhu, poprípade aj jeho inundačného územia. Už pri posudzovaní vodných nálezoch žrd’ovo-bodných zbraní zo včasného stredoveku z územia Karpatskej kotliny (Husár 2016, 13; 2016a, 134) vyplynuli nasledovné možné príčiny ukladania/objavenia sa nami posudzovaných nálezov vo vodných plochách: ukladanie z kultových alebo náboženských dôvodov, náhodná strata, strata počas bojovej akcie, nález patril k nejakému sídlisku či pohrebisku/cintorínu, šlo o odplavenie predmetu na neurčitel'nú vzdialenost' od miesta ich pôvodného uloženia, alebo o úmyselné zbavovanie sa predmetu (pozri tiež Anders-Gringmuth-Dallmer 2015, 14; Clark 2013, 18; Scholtz 2007, 250). K ojedinelým nálezom v archeologickej literatúre zarad'ujeme predmety, ktoré sa náhodne stratili, respektíve ich pôvod nevieme uspokojivo vysvetlit' (Eggert-Samida 2013, 34; Podborský 2012, 41). K depotom z vodných plôch patria nálezové celky, pri ktorých už nebola ambícia spätne ich vyberat', pretože samotný charakter miesta by to už bezpečne neumožňoval (Eggert-Samida 2013, 40-41; Podborský 2012, 40-41). Takéto depoty museli byt' tým pádom ukladané iba z kultových alebo náboženských dôvodov. Samozrejme treba pamätat' aj na to, že depot nemusí byt' len súborom uložených predmetov, ale je aj nálezový celok o jednom predmete (Eggert-Samida 2013, 39-40). Je na samotnom archeológovi,

3 Česká cesta bola súčast'ou dôležitej komunikácie, ktorá viedla od vtedajšieho Konštantínopola cez Belehrad, Budín, Ostrihom, Trnavu a Brno do Prahy. Zaujímavý dokument viažuci sa k Českej ceste sa zachoval z roku 1336. Uhorský král' Karol Róbert z Anjou (1301/1307/13081342) a český král' Ján Luxemburský (1310-1346) vydali v danom roku listinu, ktorá sa týkala zabezpečenia bezpečnosti na tejto ceste (Janšák 1961, 83-85). 
ako dostatočne interpretuje, respektíve je mu umožnené podl'a dostupných informácií interpretovat' ten ktorý vodný nález.

Zo stredoeurópskej archeologickej a historickej spisby, ktorá sa významnejšie dotkla problematiky komunikácií, prechodov cez rieky a vodných nálezov (aj) z vrcholného a neskorého stredoveku je vhodné uviest' práce nasledovných autorov. Komunikáciami a mýtami v oblasti Považia, ako aj prechodmi cez Váh v období vrcholného a neskorého stredoveku sa na základe výskumu písomných prameňov zaoberal Dušan Dzuro (2017, 82-122). Mýtne pomery na strednom a dolnom Považí v rovnakom období spracoval Peter Ivanič $(2017,59-68)$. Ďalej treba spomenút' i diplomovú prácu Michala Labudu (2016), ktorá sa venuje chladným zbraniam z 10.-16. storočia z rieky Váh, alebo článok Vladimíra Turčana $(1999,73-84)$ pojednávajúci o vybagrovaných nálezoch z rieky Dunaj, ktoré sú uložené v Slovenskom národnom múzeu Archeologickom múzeu v Bratislave. Vodné nálezy z Hlohovca a jeho okolia už dlhšie obdobie sleduje Jozef Urminský $(1995,132 ; 2003 ; 2018 ; 2019)$. Stredovekým prístavom a mýtam v okolí Bratislavy sa venoval Juraj Šedivý (2014, 343-370). Len nedávno bola publikovaná obsiahla monografia o mýtach mad’arskej historičky Boglárky Weisz (2013). Autorka spracovala typológiu colných poplatkov a priblížila colnú politiku uhorských panovníkov do konca vlády Karola Róberta z Anjou. Hlavnou častou práce je katalóg lokalít, kde sa v tomto období vyberalo mýto (aj cestné) alebo spomínali významné brody/prievozy na území Uhorského král’ovstva.

Pri chronologickom zaradení artefaktov do vrcholného a neskorého stredoveku, a hlavne tých, ktoré sú z kovu, a tým pádom často chronologicky citlivé, sme sa väčšinou uchyl'ovali k ich nutnému predatovaniu, ako v prípade nálezov amatérskych archeológov z koryta Váhu z okresu Šal'a, alebo sme siahli po recentných syntetických prácach, ktoré pri určitých druhoch zbraní spomínaný chronologický posun už urobili. ${ }^{4}$

\section{Od Komárna po Trenčín}

Pri sútoku Dunaja a Váhu leží Komárno. Tu sa mýto vyberalo zrejme na prechode cez obidve rieky. Miriam Hlaváčková uvádza, že k významným mestským príjmom v stredoveku patrilo prievozné mýto. Pravobrežný vážsky prievoz situuje do blízkosti hradu a l’avobrežný mal existovat' pri zaniknutej dedine Halas (Hlaváčková 2010, 183). V roku 1286 uhorský panovník Ladislav IV. (1272-1290) potvrdil Kláštoru sv. Maurícia v Bakonybély vlastníctvo dvoch tretín z prístavného a trhového mýta v Komárne (Camarun; Knauz 1882, 214 č. 190). Mýto sa spomína vo vlastníctve kláštora aj v roku 1306 (RDSI I, 192 č. 414; 194 č. 419). Zmienka o ňom je aj v listinách král’a Karola Róberta z Anjou z rokov 1315 a 1320 (RDSI II, 43 č. 51; 259 č. 563). Ked' dostal v roku 1422 palatín Mikuláš z Gorjan do zálohu od panovníka Žigmunda Luxemburského (1387-1437) hradné panstvo Komárno, tak sa medzi príslušenstvom uvádzajú mýta na Dunaji spolu s mestom a mýtom v Komárne. V dokumente je zmienka o tom, že panstvu patrilo aj mýto z Dunaja a Váhu okrem mýta z brodu na riekach Dunaj (Danubii) a Váh (Wagh) v Dunaalmási (Almas) a Komárne (ZSO IX, 194 č. 608-609). Ked’že Dunaalmás je situovaný na pravom brehu Dunaja, tak mýto pri brode cez Váh sa platilo jedine v Komárne. Práve Komárno bolo už od 14. storočia najdôležitejším strediskom obchodu s drevom, dovážaného pomocou pltí predovšetkým z Oravy a Liptova (Slavkovský 2014, 105).

Podla našich informácií neexistujú žiadne nálezy, ktoré by sa dali jednoznačne spojit' s korytom Váhu a spomínaným brodom v priestore Komárna. Michal Labuda (Labuda 2016, 130-140, 147, obr. 124-132) uviedol, že 8 mečov, z ktorých 6 sa dá datovat' do 12. až 14. storočia, je uložených v Podunajskom múzeu v Komárne. Pri dvoch ich stav neumožňuje presnejšie datovanie. Ďalej spomínaný bádatel' (Labuda 2016, 147) napísal, že ich nálezové okolnosti nie sú známe v rámci katastrálneho územia Komárna, pretože nemuseli pochádzat' len z rieky Váh, jej záplavového pásma, ale aj z rieky Dunaj, či z inej nálezovej situácie nespájajúcej sa s vodným prostredím. Dané meče Alexadner T. Ruttkay (1975, 199-204, Abb. 25-27), spolu s d’alšími

4 Pre meče a tesáky pozri napríklad už vyššie spomínanú prácu od Michala Labudu (2016). 


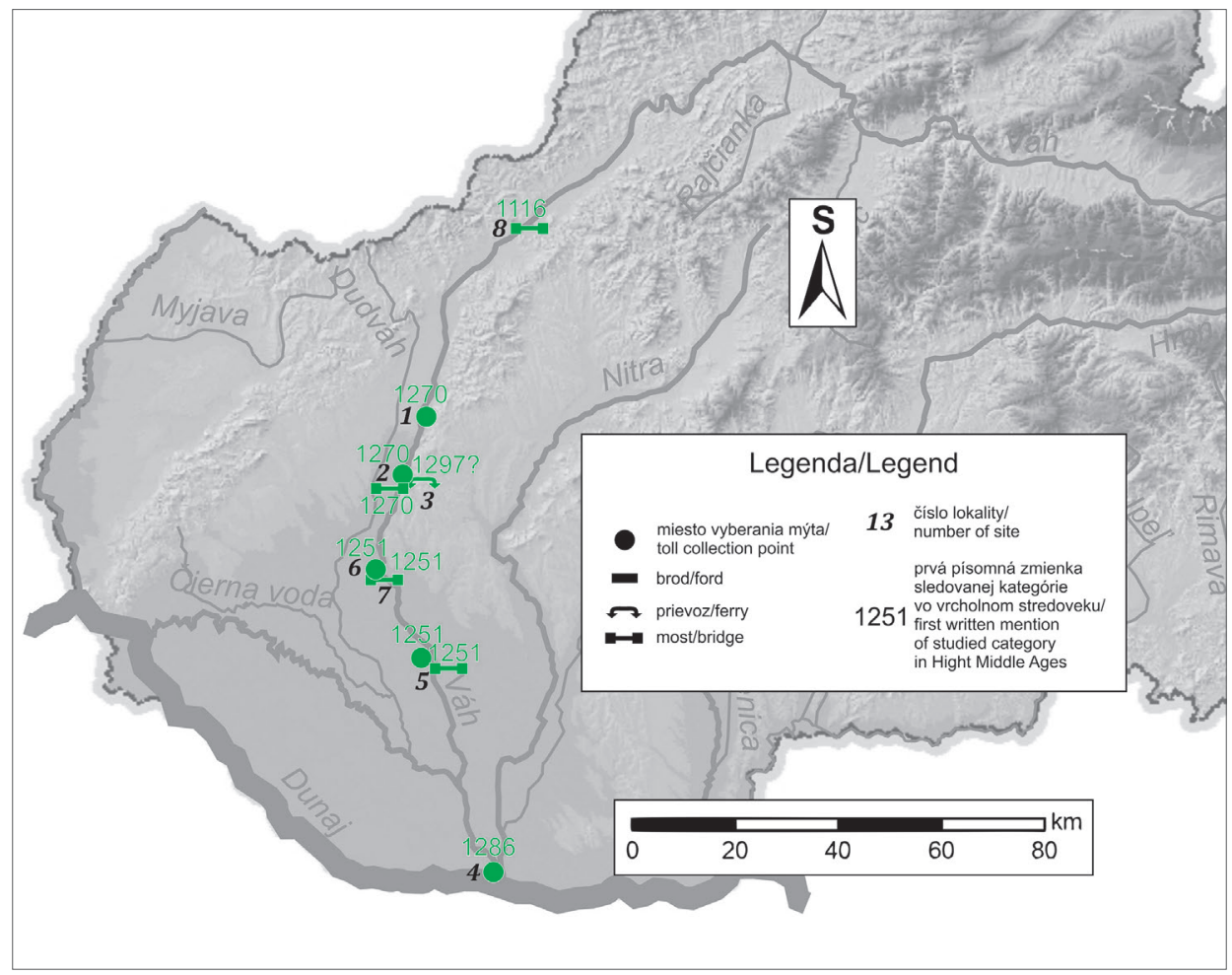

Obr. 1. Mýta, brody, prievozy a mosty na dolnom a strednom Považí vo vrcholnom stredoveku, druhá polovica 11. storočia 13. storočie. Lokality: 1 - Banka; 2 - Hlohovec; 3 - Hlohovec (Sv. Peter) + Červeník; 4 - Komárno; 5 - Šal'a; 6 - Šintava; 7 - Šintava + Sered'; 8 - Trenčín.

Abb. 1. Mautstellen, Furten, Fähren und Brücken im unteren und mittleren Waag-Gebiet im Hochmittelalter, zweite Hälfte 11. Jhdt. - 13. Jhdt. Fundstellen: 1 - Banka; 2 - Hlohovec; 3 - Hlohovec (Svätý Peter) + Červeník; 4 - Komárno; 5 - Šal'a; 6 - Šintava; 7 - Šintava + Sered'; 8 - Trenčín.

nálezmi zo spomínaného múzea, konkrétne spolu so štyrmi strmeňmi, 9 ostrohami, tromi uzdami, 12 hrotmi kopijí/oštepov a 9 hlavicami sekier, zaradil k nálezom z bývalej Komárňanskej župy, pričom ich datoval pred 14. storočie. Zo súboru vyplýva, že niektoré z nich časovo siahajú aj do včasného stredoveku. ${ }^{5}$ Zaujímavým faktom je, že v rámci Prvého vojenského mapovania Uhorska (1782-1785) sa v priestore Komárna nachádzala kompa približne v mieste dnešného cestného mostu cez Váh (Die Josephinische Landesaufnahme 1782-1785).

Smerom hore prúdom Váhu od Komárna k Šali evidujeme skupinu vodných nálezov z katastrálnych území dnešných obcí Neded, Vlčany, Selice a Trnovec nad Váhom, ktoré nemajú oporu v písomných prameňoch. Zo starého koryta (mŕtveho ramena) Váhu v obci Neded pochádza niekol'ko fragmentov keramiky zo 14. a 16. storočia, ktoré tu boli nájdené Zoltánom Vozákom pri prehlbovaní a zároveň bagrovaní piesku v rokoch 1995-1998 (Vozák-Kormoši 2013, 130). Tiež z 37. a 38. riečneho kilometra koryta Váhu pri Nedede sa v roku 1998 zachránilo vyššie uvedeným bádatel'om viacero fragmentov keramických nádob z 12. až 16. storočia, popri iných z praveku (Vozák-Kormoši 2013, 125-130). Z neskoršieho Prvého vojenského mapovania Uhorska (1782-1785) vieme identifikovat' drevený most na pilieroch cez spomínané mútve

5 Problémom je i skoro úplná absencia výskumných správ a inventárnych kníh spred roka 1945. Za túto informáciu d’akujeme archeológovi Podunajského múzea v Komárne Mgr. Andrásovi Csuthymu, PhD. 
rameno v obci Neded, ktorý bol v tom období na trase cesty pre vozy z Nededu do Vlčian. Druhá spomínaná lokalita v koryte Váhu na jeho 37. a 38. riečnom kilometri bola v rámci Prvého vojenského mapovania Uhorska na mieste kompy, do ktorej ústili cesty prichádzajúce do Nededu Z vtedajších Selíc a Palárikova (Die Josephinische Landesaufnahme 1782-1785). Na 41. riečnom kilometri koryta Váhu pri Vlčanoch, kde sa rieka rozširuje a vytvára sa tu značná piesčina, zachránil Zoltán Vozák pri t’ažbe štrkopieskov (do hĺbky 6 m) v roku 1988, popri kostiach zvierat, keramických fragmentoch z praveku, doby rímskej a novoveku, aj keramiku z 12. až 16. storočia, ako aj zlomok kachlice zo 16. storočia. Ako zdroj daného materiálu určil pravostranný podmytý breh Váhu (Vozák-Kormoši 2013, 118, 124-125). Južnejšie od poslednej menovanej lokality sa nachádzala v Prvom vojenskom mapovaní kompa medzi Vlčanmi a cestami vedúcimi na Selice a Palárikovo (Die Josephinische Landesaufnahme 1782-1785). Ďalšie nálezy pochádzajú z Váhu pri obci Selice, kde v roku 1989 prebiehala úprava koryta Váhu na jeho 45. až 47 riečnom kilometri. Okrem paleontologického materiálu, zlomkov keramiky z praveku a doby rímskej, sa z vybagrovaného materiálu dostali na povrch i črepy vrcholno- a neskorostredovekej keramiky (11. storočie až začiatok 16. storočia) a zlomok strešnej krytiny z novoveku (Vozák-Kormoši 2013, 155-158). Takisto sa tu objavila i jedna železná ostroha s ozubeným kolieskom a zachovanou prackou (Vozák-Kormoši 2013, 158, tab. 162:1). Tú môžeme podl'a analógií datovat' od druhej polovice 15. do 16./17. storočia (Koóšová 2007, 260, tab. 2). Prvé vojenské mapovanie môže zmienenú lokalitu spájat' v danom mieste s kompou, do ktorej ústili cesty zo Selíc a Žihárca, a takisto boli na ned’alekom pravom brehu Váhu zo strany Žihárca dva vodné mlyny (Die Josephinische Landesaufnahme 1782-1785). Popri inom archeologickom materiáli, väčšinou keramike, sa fragmenty neskorostredovekej keramiky našli i v rámci d’alších dvoch lokalít z koryta Váhu pri Seliciach v rokoch 1994-1998. Ide o 43. riečny kilometer koryta Váhu a dnes už priestor Vodného diela Selice. V prvom prípade sa odkryl fragment keramiky zo 14. storočia a druhom prípade dva črepy z 15. i 16. storočia (Vozák-Kormoši 2013, 159, 161-163). V priestore dnešného Vodného diela Selice sa v období Prvého vojenského mapovania nachádzal na l'avom brehu Váhu majer/statok, z ktorého vychádzali cesty na obec Selice a Palárikovo (Die Josephinische Landesaufnahme 1782-1785). Na 52. riečnom kilometri Váhu, pri obci Trnovec nad Váhom, boli v roku 1988 Zoltánom Vozákom zachránené z vybagrovaného štrkopiesku fragmenty keramiky z 13. storočia, odhliadnuc od iných častí keramických nádob z praveku a kostí pleistocénnych zvierat (Vozák-Kormoši 2013, 138).

Na dolnom Považí existoval d’alší prechod cez rieku medzi Šal’ou a Večou. V roku 1251 sa spomína, že dve tretiny z mýtnych poplatkov, ktoré sa vyberali na moste a v prístave v Šali (Sala), sa odvádzali premonštrátskemu Kláštoru Blahoslavenej Panny Márie v Turci (CDSl II, 257 č. 370). Takisto je to uvedené aj o rok neskôr (CDS1 II, 277 č. 400). ${ }^{6}$ Spomínanému kláštoru potvrdil v roku 1297 vlastníctvo mýta na moste a v prístave v Šali aj pápež Bonifác VIII. (HOKL, 155 č. 149). Dokument z roku 1318 uvádza, že podiel z výnosu mýta malo pôvodne aj Nitrianske biskupstvo. Na začiatku 14. storočia si ho privlastnil významný uhorský šlachtic Matúš Čák (RDS1 II, 151 č. 312). Zaujímavost'ou je, že na najstaršej pečati Veče (18. storočie) sú zobrazené krížom preložené veslá, cez stred ktorých je položený hák na otáčanie lodí (História mestskej časti Veča 2016; Máj 2003 pri príležitosti 890. výročia). V rámci Prvého vojenského mapovania nebol medzi Šalou a Večou vyššie spomínaný stredoveký most zaznamenaný a figuruje tam iba prievoz/kompa (Die Josephinische Landesaufnahme 1782-1785). Nitrianske biskupstvo si podla listiny z roku 1271 robilo nárok aj na mýto v prístave na rieke Dudváh (Dodwagh) v Horných Salibách (Scele), na juhozápad od Šale (MNL OL DF 273054; CDH VII/2, 152 č. 405). . V tomto prípade ide o jedinú zmienku o tunajšom mýte a prístave.

Z koryta Váhu pri Šali a Šali-Veči, kde sa v období vrcholného a neskorého stredoveku nachádzal i prístav a most, pochádza vel’mi bohatý nálezový fond z preberaného obdobia, ktorý

6 V roku 1267 bol most násilne zabraný Bartolomejom a Urbanom, šlachticmi z Veče (HOKL, 52 č. 43). Mad’arská historička Boglárka Weisz $(2013,336)$ si myslí, že z tohto dôvodu vybudoval Belo IV. (1235-1270) nový most medzi Trnovcom nad Váhom a osadou Dvorec, ležiacou južne od Šale.

7 Otázna je však pravost' dokumentu (RRSA II, 113 č. 2106). 
sa do povedomia, ako aj predchádzajúce nálezy od Nededu pod Trnovec nad Váhom, dostal vd’aka dlhoročnej bádatel'skej činnosti členov súčasného Archeologickému krúžku Centra vol’ného času Tip Top v Šali. ${ }^{8}$ Alexander T. Ruttkay uviedol ešte v roku 1975, že pät' rokov predtým (1970) narazil bagrista pri bagrovaní vo Váhu na sever od železničného mosta v Šali (spájajúci Šalu s Trnovcom nad Váhom) na viacero (stredovekých?) mečov a sekier, ktoré boli však už v prv spomenutom roku stratené (Ruttkay 1975, 138). Z kontextu nálezovej správy Archeologického ústavu Slovenskej akadémie vied č. 5181/70 však vyplýva, že vyššie uvedené nálezy sa môžu týkat' skôr katastra súčasnej obce Dlhá nad Váhom a pri železničnom moste sa podl’a doktora Cyrila Ambrosa našli nešpecifikované nálezy, medzi ktorými spomenul len zub srstnatého nosorožca, vel’a kostí mamuta a kalvu pračloveka (Nálezová správa AÚ SAV č. 5181/70). Vodné nálezy zo Šale sa d’alej koncentrujú od 55. do 59. riečneho kilometra koryta Váhu. V rokoch 1982 až 1993 členovia vyššie uvedeného archeologického krúžku počas permanentných obhliadok t’ažby štrkopieskov v koryte Váhu (do híbky $10 \mathrm{~m}$ ) získali vel'ké množstvo archeologického materiálu od obdobia praveku až do 18. storočia (Vozák-Kormoši 2013, 52-61). Popri fragmentoch keramiky a kachlíc z vrcholného a neskorého stredoveku sa tu našlo aj niekol'ko kovových predmetov datovatel'ných do rovnakého obdobia stredoveku. ${ }^{9} \mathrm{Z}$ 56. riečneho kilometra Váhu bola v roku 1998 vytiahnutá hlavica sekery, ktorú vieme zaradit' podl'a analógií do 7. až 13. storočia (Dostál 1966, 71, obr. 15:10; Głosek 1996, 33-34, 80, tabl. IX:A-B; Йотов 2004, 91, 101, таблица 16:2.B, 1.8.A; 17; Kotowicz 2014, 80, 89, 165, 206, tabl. XLVI:1; LIV:2; CXXVI:4; CLX:2, nr kat. 291, 331, 645, 840; Ruttkay 1982, Table II:28; Szücsi 2013-2014, 169, I. tábla). Na rovnakom riečnom kilometri boli o rok neskôr nájdené, okrem kostí pleistocénnych zvierat, aj vrcholnoa neskorostredoveké zbrane a súčasti konského postroja - ostroha, štyri podkovy a jeden meč. ${ }^{10}$ Vyššie spomenuté lokality vodných nálezov zo Šale môžeme spojit's kompou a vodným mlynom (na l'avom brehu) na rieke Váh, ktoré sú zobrazené na Prvom vojenskom mapovaní Uhorska. Daná kompa spájala cesty z Veče do Šale a Královej nad Váhom (Die Josephinische Landesaufnahme 1782-1785). V mítvom ramene Váhu na území Šale-Veče ned’aleko lodenice, našiel Zoltán Vozák okrem fragmentov keramiky z doby rímskej a nedatovaných kostí zvierat i keramiku zo 14. až 17. storočia (Vozák-Kormoši 2013, 62-63) a visiaci zámok s dutým telom a pántovým ramienkom (Vozák-Kormoši 2013, 63, tab. 54:9). Podl’a klasifikácie Zdeňka Rasla (1987, 155, obr. 8) ho vieme priradit' $\mathrm{k}$ strmeňovým pružinovým zámkom, pôvodne s otočnými kl'účmi, a tým pádom podl’a paralel od polovice 14. do 16. storočia. Uvedenú lokalitu zo Šale-Veče možno prostredníctvom Prvého vojenského mapovania Uhorska spojit's existenciou vodného mlyna v danom priestore na l'avom brehu Váhu (Die Josephinische Landesaufnahme 1782-1785).

Ned’aleko Šale sa proti prúdu Váhu dotýkajú rieky katastrálne územia obcí Dlhá nad Váhom (na l'avom brehu rieky) a Král'ová nad Váhom (na pravom brehu rieky), pri ktorých sa v písomných prameňoch nespomínajú v sledovanom období stredoveku žiadne prechody. Nie všetky vodné nálezy týkajúce sa koryta Váhu pri Dlhej nad Váhom majú jasné nálezové okolnosti, resp. nemôžeme ich s úplnou istotou k vodným nálezom pričlenit', a naviac nevieme, na ktorom presnom úseku koryta Váhu sa dané artefakty našli. Najmenej tri meče z nich, vybagrované v minulosti Vojtechom Takáčom a Františkom Babóssom v roku 1963 v koryte Váhu (Nálezová správa

\footnotetext{
8 V tejto súvislosti ide najmä o významný osobný prínos Zoltána Vozáka a Jána Kormošiho zo Šale.

9 Podkovy (Vozák-Kormoši 2013, tab. 54:1-8; 55:2, 4) môžeme podl’a paralel datovat' do konca 12. storočia až do začiatku 17. storočia (Baxa 1981, obr. 12; Imhof 2010, Tabelle 1; 2; Clark ed. 1995, 86-97, Fig. 65; 69; 74; 75). Ostrohy (Vozák-Kormoši 2013, 61, Tab. 56:4-5, 7-8) vieme podl'a analógií zaradit' do 14. storočia až 1. polovice 15. storočia (Koóšová 2004, Tab. 1; 2; 2007, Tab. 2). Osemlistovú hlavicu palcátu (VozákKormoši 2013, 61, tab. 57:3) by sme mohli klást' do 16. storočia (Kovács 2016, 71, Fig. 24). Dve šable (Vozák-Kormoši 2013, 61, tab. 57:1-2) môžu byt' datované do 16. až 17. storočia (Kalmár 1971, 135., 136., 143. kép). Bojovú kosu datujú Zoltán Vozák a Ján Kormoši (2013, 61, tab. $57: 8$ ) do 15. storočia. Stredoveké sekery (Vozák-Kormoši 2013, 61, tab. 56:1-3,6) sa dajú na základe analógií datovat' od 8./11. storočia do 16. storočia (Głosek 1996, 29-31, 42-43; 50-51, 80, 89, tab. IV:If; VI:C; VII; VIII; XIa; XXII; XXIII; XXX:C [sub-type XIa]; Heindel 1992, 36, Abb. 16:a; 19; Кирпичников 1966, 38, рис. 6 [type VA]; Kotowicz 2014, 169, tabl. CXXIX:3 [nr kat. 662]; Novotný 1965, 75-76, 78, tabul'ka XII:8; Терський 2005, 21, Рис. 4:17; Žákovský 2011, 158, obr. 8:5, tab. XI:4). Dva hroty striel do kuše (Vozák-Kormoši 2013, 61, tab. 57:4-5) zarad'ujeme podl'a paralel do 13. až 14. storočia (Serdon 2005, 124, Figure 39-40 - de types Zimmermann D 2-5; Ruttkay 1976, 331-332, Abb. 54:B11-Typus 11). Pracka bola datovaná do 15. storočia (Vozák-Kormoši 2013, 58, tab. 51:4).

10 Ostroha (Vozák-Kormoši 2013, 62, tab. 55:8) sa dá zaradit' do 12. - prvej polovice 13. storočia (Koóšová 2004, 540-541, tab. 1-2; Ruttkay 1976, 349-350, Abb. 72:B3), štyri podkovy (Vozák-Kormoši 2013, 62, tab. 55:3, 5-7) od 11. až do 13. storočia / 1. polovice 14. storočia (Imhof 2010, 23-25, Tabelle 1-2; Baxa 1981, 435, obr. 12) a meč (Vozák-Kormoši, 62, tab. 55:1) do prvej polovice 15. storočia (Aleksić 2007, 68-69, 97-99, Fig. 1; 4).
} 


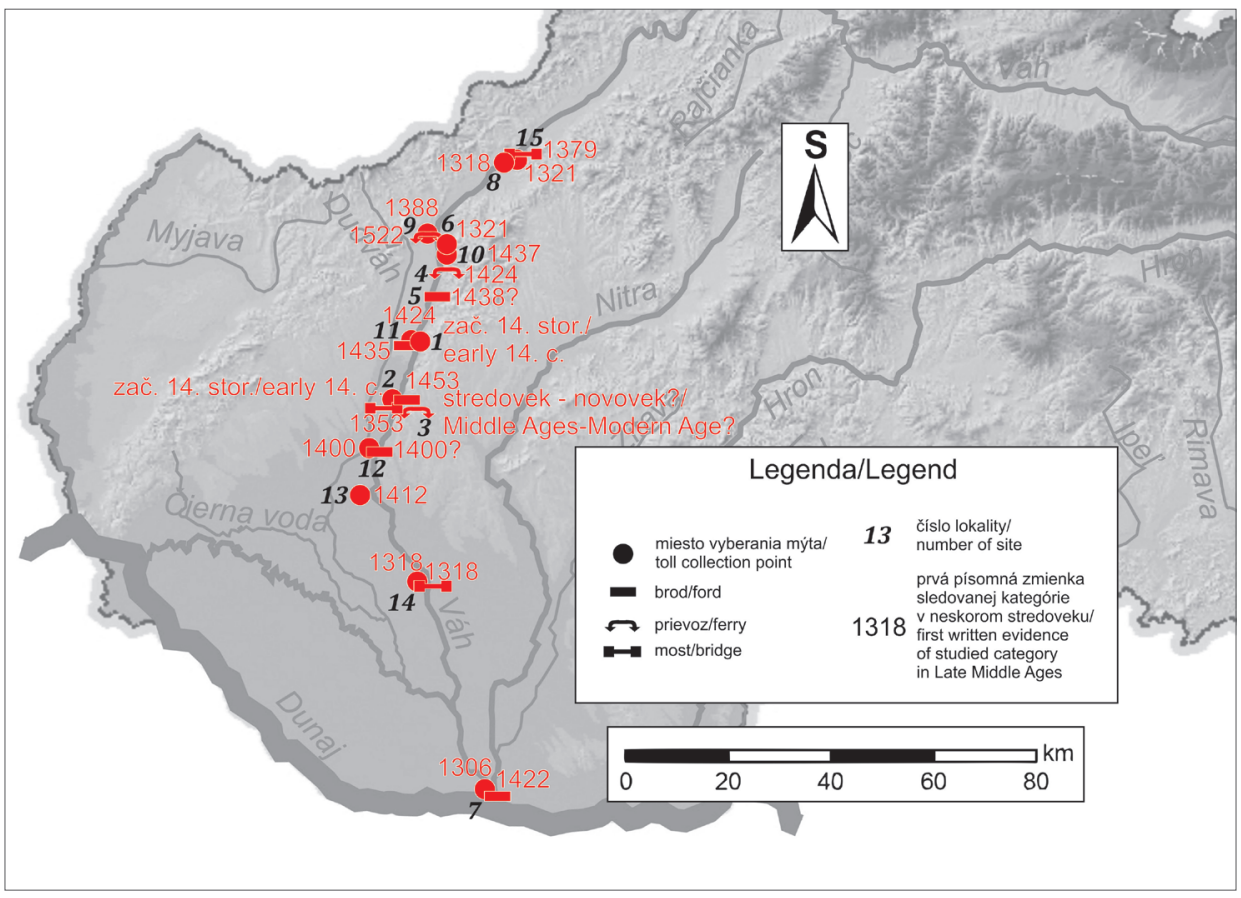

Obr. 2. Mýta, brody, prievozy a mosty na dolnom a strednom Považí v neskorom stredoveku, 14. storočie - prvá polovica 16. storočia. Lokality: 1 - Banka; 2 - Hlohovec; 3 - Hlohovec (Svätý Peter) + Červeník; 4 - Hrádok; 5 - Hubina-Závažie; 6 - Kočovce; 7 - Komárno; 8 - Kostolná-Záriečie; 9 - Nové Mesto nad Váhom; 10 - Nová Ves nad Váhom; 11 - Piešt’any; 12 - Pintekova Ves; 13 - Sered'; 14 - Šal'a; 15 - Trenčín.

Abb. 2. Mautstellen, Furten, Fähren und Brücken im unteren und mittleren Waag-Gebiet im Spätmittelalter, 14. Jhdt. erste Hälfte 16. Jhdt. Fundstellen: 1 - Banka; 2 - Hlohovec; 3 - Hlohovec (Svätý Peter) + Červeník; 4 - Hrádok; 5 - Hubina-Závažie; 6 - Kočovce; 7 - Komárno; 8 - Kostolná-Záriečie; 9 - Nové Mesto nad Váhom; 10 - Nová Ves nad Váhom; 11 - Piešt'any; 12 - Pintekova Ves; 13 - Sered'; 14 - Šal'a; 15 - Trenčín.

AÚ SAV č. 1468/63), sa dajú bezpečne zaradit' do druhej polovice 13. a začiatku 14. storočia (Ruttkay 1975, 138, Abb. 5:1, 5, 3; 12:2; 14:1, 2; Labuda 2016, 122-127, obr. 119-123). Uvedené meče z Váhu neboli však osamotenými predmetmi, ktoré Takáč s Babóssom našli, pretože zvyšné nešpecifikované predmety (spolu s nejakým kalichom) nálezcovia hodili spät’ do rieky (Nálezová správa AÚ SAV č. 1468/63; Ruttkay 1975, 138). Pri d’alších vodných nálezoch mečov, hlavíc sekier a keramiky z Dlhej nad Váhom môžeme stredoveké datovanie len predpokladat'. V tejto súvislosti môžeme uvažovat' aj o možnom stredovekom datovaní dvoch hlavíc sekier zaznamenaných v nálezovej správe od Júliusa Rajčeka z roku 1963 (Nálezová správa AÚ SAV č. 1468/63). V roku 1967 Ladislav Beneš vybagroval meč z brehu Váhu, konkrétne spod 8 metrovej híbky pod nánosom piesku (Nálezová správa AÚ SAV č. 3926/67; Labuda 2016, 128; Ruttkay 1975, 138). Pravdepodobne stredoveké zbrane (dva meče s bronzovou výzdobou na čepeli i dve hlavice sekier označené v nálezovej správe od Cyrila Ambrosa ako tesárske alebo pltnícke) a stredoveké nádoby, ktoré môžu byt' ale stratené alebo vo Vlastivednom múzeu v Galante, vybagroval z Váhu pri obci Dlhá nad Váhom v minulosti Jozef Shadi (Nálezová správa AÚ SAV č. 5181/70; Labuda 2016, 128; Ruttkay 1975, 139). Michal Labuda priradil (bez istoty) k možným nálezom mečov z Váhu pri Dlhej nad Váhom i d’alšie dva exempláre, toho času uložené vo Vlastivednom múzeu v Galante (Labuda 2016, 88-92, obr. 85-92). Prvý z nich datoval do prelomu 12. a 13. storočia (Labuda 2016, 88) a druhý do 14. storočia (Labuda 2016, 91). Posledne spomínaný autor 
tiež uvažuje o brode (Labuda 2016, 147), ktorý sa nachádzal pri Dlhej nad Váhom, no nie je pre to podklad ani v písomných a ani kartografických prameňoch. Pri stavbe vodnej nádrže Králová bol Slavomírom Zuščákom v katastrálnom území obce Král'ová nad Váhom (bez presného miesta určenia) vybagrovaný hrot kopije/oštepu (Slivka 1985, 213, obr. 82). Ide o hrot, ktorý má maximálnu šírku listu menšiu než maximálnu šírku tul'ajky, a preto ho môžeme nazvat' skôr bodcom. Navyše má i sférický výčnelok v mieste kŕčku. Bodce sa v euroázijskom priestore dajú datovat' od 2. a 1. storočia pred Kr. do 14. storočia (Husár 2014, 21-22 - tam aj d’alšia literatúra). Sférické výčnelky sú na hrotoch kopijí/oštepov z Európy známe však bezpečne od poslednej štvrtiny 7. storočia do 14. storočia (Husár 2017, 117 - tam aj d’alšia literatúra). Preto spomínaný bodec z Král'ovej nad Váhom vieme zaradit' do obdobia od konca 7. do 14. storočia. Pred výstavbou vodnej nádrže Král'ová Váh v danej oblasti výrazne meandroval a pri dnešnej obci Král'ová nad Váhom sa v čase Prvého vojenského mapovania nachádzalo až osem vodných mlynov na pravom brehu Váhu (Die Josephinische Landesaufnahme 1782-1785).

Ďalšie vrcholno- a neskorostredoveké vodné nálezy, ktorých existencia nemá oporu v písomných prameňoch, sa viažu v smere proti prúdu Váhu na katastrálne územie obce Šoporňa. V roku 1971 tam v mótvom ramene Váhu našiel P. Antoš v časti Pasienok pri tažbe štrkopieskov fragment železného meča (Katkin 1996, 106, obr. 73; Labuda 2016, 120-121, obr. 118) aj so siedmimi kusmi ostrôh. Tie ostrohy však ostali na mieste a neboli podrobené d’alšiemu skúmaniu ako spomínaný meč, ktorého torzo vieme zaradit' do 12. až 15. storočia (Labuda 2016, 120). V Šoporni-Štrkovci, konkrétne na Galantskej sihoti, sa v roku 1977 našlo pri bagrovaní vodného diela Král’ová viacero nálezov a medzi nimi aj sedem železných mečov, ktorých uloženie nie je dnes známe a vieme len, že boli datované do 12.-14. storočia (Bialeková ed. 1989, 104). Z neznámej polohy v Šoporni-Štrkovec evidoval jeden meč uložený vo Vlastivednom múzeu v Galante aj Michal Labuda. Ten ho datoval od polovice 13. do polovice 15. storočia (Labuda 2016, 79-80, obr. 71-74).

Významný prechod cez Váh na známej Českej ceste existoval medzi Šintavou a Sered’ou. Už v roku 1251 sa spomína, že dve tretiny z mýta v prístave a na moste v oblasti pri hrade Šintava (castrum Symtey) získal premonštrátsky Kláštor Blahoslavenej Panny Márie v Turci (CDS1 II, 257 č. 370). Daný prameň nám dokladá most i prístav na rieke Váh. O rok neskôr uhorský panovník Belo IV. vydal listinu, kde uvádza, že mýto sa vyberalo nielen od spomínaného mostu, prístavu a plavidiel, ale aj zo splavovaného dreva a na brodoch i mostoch v uvedenej oblasti. Premonštráti mali mat príjem nielen z mýta už na existujúcich brodoch a mostoch, ale aj na takých, ktoré sa mali zriadit' (CDS1 II, 277 č. 400). Aj v tomto prípade bol podiel z mýta odvádzaný Nitrianskemu biskupstvu. Na začiatku 14. storočia si ho privlastnil magnát Matúš Čák (RDS1 II, 151 č. 312). Dokument z roku 1412 svedčí o výbere mýta na pravom brehu Váhu v susednej Seredi (Zereth) a v ned’alekých Vlčkovciach (Farkashyda) na Dudváhu. Poplatok mali platit' cestujúci, ktorí bývali medzi Váhom a Dudváhom a chodili na trh do Hlohovca. V listine sa d’alej píše, že od poplatku boli oslobodení pocestní, ktorí smerovali z Hlohovca do Šale (Sellye). Zároveň aj obyvatelia sídiel medzi Majcichovom (Mayteh) a Brestovanmi (Zely) po oboch stranách Dudváhu nemuseli platit' mýto (MNL OL DL 9869; ZSO III, 398-399 č. 1584). Obidve mýta sa spomínajú aj v roku 1419 vo vlastníctve panstva Šintava, ked' ich aj s ostatným príslušenstvom získal do zálohu za 10500 zlatých gróf Juraj z Pezinka (MNL OL DL 10970; ZSO VII, 246 č. 932).

Vd’aka analýze vodných nálezov na vyššie uvedenom (mostnom) prechode na Českej ceste vieme povedat' nasledovné: z priestoru bývalého vodného hradu Šintava, ${ }^{11}$ ktorý priamo strážil prechod cez Váh v danej oblasti, pochádzajú štyri meče, ktoré sa dajú zaradit' od 12. storočia do prvej štvrtiny 15. storočia a dnes sú uložené Mestskom múzeu v Seredi (Labuda 2016, 65-76, obr. 48-66). Ďalší nález meča (zo začiatku 13. storočia), nachádzajúci sa dnes vo Vlastivednom múzeu v Galante, je z neznámej polohy v rámci katastrálneho územia Serede a nevieme ho jednoznačne spojit's korytom Váhu (Labuda 2016, 74-76, obr. 62-66). Na mape Prešporskej stolice z roku 1736 od Samuela Mikovíniho vidíme pravdepodobne drevený most cez Váh, ktorý sa

11 Dnes sa už hrad Šintava nachádza na pravom brehu Váhu v Seredi, pretože pravdepodobne niekedy v 16. storočí sa zmenil tok koryta Váhu tak, že ho oddelil od mestečka Šintava (Labuda 2016, 65). 
t’ahá od jeho pravého brehu zo strany Serede ned’aleko barokovej pevnosti súvisiacej s hradom Šintava smerom na východ k l'avému brehu Váhu a priestorom na sever od Šintavy (Občianske združenie Vodný Hrad). Drevený most je situovaný o niečo vyššie po prúde rieky Váh v rámci Prvého vojenského mapovania, na sever od Serede a Šintavy (Die Josephinische Landesaufnahme 1782-1785). Taktiež do samotného hradu Šintava sa muselo vstupovat' počas vrcholného a neskorého stredoveku cez (drevený) most ponad (zavodnenú) priekopu (Plaček-Bóna 2007, 293-295, obr. 394-395).

Mýtne poplatky na Váhu sa tiež vyberali v Pintekovej Vsi (Pintechfalwa) $)^{12}$ pri dnešných Dolných Zeleniciach, ako o tom svedčí listina z roku 1400. Tu je možné predpokladat' i brod cez rieku (ZSO II/1, 68 č. 563).

S vyššie spomenutým brodom mohli súvisiet' i nálezy z pieskovej duny nad korytom Váhu v Dvorníkoch, polohe Červeníky. Tam sa kvôli t’ažbe piesku natrafilo v rokoch 1992-1993 na stredovekú vrstvu s popolom a prepáleným pieskom, z ktorej sa zachránil tesák (Labuda 2016, 115-117, obr. 115-117; Urminský 1995, 132, obr. 104), fenig Žigmunda I. zo Salzburgu (14521461), hlavica sekery a kúsky skorodovaného železa (Urminský 1995, 132). Nálezy vieme datovat' do polovice 15. storočia (Labuda 2016, 115). Na prostredie vyššie uvedeného brodu sa môže viazat' i nasledovný nález. Recentne L'ubica Oláhová našla na l’avom brehu rieky Váh medzi Posádkou, miestnou čast’ou obce Dvorníky, a chatovou osadou Berek 8 do seba vklinených hrotov kopijí/oštepov, ktoré boli skorodované a obalené riečnymi kameňmi (Urminský 2019). Podl’a fotografie, ktorú nám poskytlo Vlastivedné múzeum v Hlohovci, ${ }^{13}$ môžu mat' tieto hroty tul'ajky a niektoré z nich i relatívne dlhé a úzke trojuholníkové listy s najväčšou šírkou v ich spodnej časti, pričom u nich asi absentuje výrazné stredové rebro. Nie príliš presné údaje k daným hrotom s trojuholníkovým listom nás môžu viest' iba k vel'mi široko ohraničenému datovaniu. V euroázijskom priestore sa začali objavovat' už od doby železnej (Husár 2014, 61, 87, 113), pričom hroty podobné posudzovanému mohli v strednej Európe vyznievat' ešte v 14. a 15. storočí (Žákovský 2008, 480, obr. 3:2, 4-6; 4:3, 6-8).

Severne od Serede sa na hlavnej ceste Považím mýta uvádzajú v Hlohovci a jeho okolí. Konkrétne v Hlohovci (Galgoch) existoval most cez Váh už v roku 1270. Mokré mýto sa v tom čase vyberalo od všetkých tovarov a dreva splavovaného dolu Váhom. Nitriansky biskup Vincent sa vtedy st'ažoval, že po tatárskom vpáde prestali vyberači mýta odvádzat' biskupstvu desatinu poplatkov, ako bolo predtým zaužívané podl'a starej tradície (MNL OL DF 226543). Uhorský král' Ondrej III. (1290-1301) čast' král'ovského majetku vrátane podielu z mýta daroval v roku 1294 Abrahámovi Rufusovi. Tento si právo vyberat' mýto ponechal aj potom, čo v roku 1297 vymenil svoj podiel na majetku v Hlohovci s Abom z rodu Abovcov za Sobotište a hrad Branč (CDAC X, 135-136 č. 92). Rufus mal zrejme nárok na mýto, ktoré sa vyberalo na prievoze cez Váh medzi Svätým Petrom ${ }^{14}$ a Červeníkom. Tento nárok zrejme s prestávkami existoval aj v novoveku. Svedčil by o tom aj zákres mýtneho domčeka (Mauth hausel) na pláne H. Kleinwächtera z roku 1728 (Pišút-Procházka-Matečný-Bandura 2016, 201-202). Výnosy z mýta si na začiatku 14. storočia privlastnil Matúš Čák (RDSl II, 152 č. 312). V roku 1353 bolo vyberanie mýta preložené so súhlasom krála na novopostavený most cez Váh (CDAC VI, 133 č. 87). Uhorský palatín Mikuláš Kont v roku 1365 vydal listinu pre obyvatel’ov Starého Hlohovca, kde sa uvádza, že sú oslobodení od platenia mýta a tridsiatku, ale ich povinnost'ou bolo udržiavat' a opravovat' most cez rieku Váh (MNL OL DL 5389). V roku 1369 získala so súhlasom L’udovíta I. Vel'kého výnosy z mýta v Hlohovci Klára, vdova po Mikulášovi Kontovi, ktorý vlastnil Hlohovec (MNL OL DL 5728, ZSO II/1, 68 č. 563). V roku 1424 sa uvádza, že v prípade, keby sa rieka rozvodnila a zničila most cez Váh, tak pocestní mali platit' len prepravu na jej druhý breh (ZSO IX, 538 č. 1348). V tomto roku hlohovecký kastelán Fekeč prepadol na moste (in ponto in fluvio

12 Mal by to byt' majer Lukáb pri dnešných Dolných Zeleniciach (Hrubý 2015, 203). Dušan Dzuro (2017, 97) však uvádza, že išlo o Horné Zelenice.

13 Za túto fotografiu a informácie, ako aj d’alšie fakty týkajúce sa archeologického bádania a vodných nálezov z Hlohovca a jeho okolia d’akujeme riaditel'ovi Vlastivedného múzea v Hlohovci Mgr. Jozefovi Urminskému.

14 Obec Svätý Peter ležala na sever od Hlohovca a k mestu bola pričlenená v roku 1953. 
Vag) richtára Vel'kých Kostolian Valentína a jeho spoločníkov (Wenzel 1874, 180). V roku 1431 most zničili husitské vojská pod vedením Prokopa Holého, ktoré táborili v blízkosti Hlohovca (Varsik 1965, 81-82). Začiatkom novembra v tom istom roku ustupovali pred uhorským vojskom sirotkovia. Zastavil ich však spálený most pri Hlohovci, a tak museli rýchle pokračovat' po l'avej strane Váhu a až pri Ilave prešli na druhý breh rieky a odtial' pokračovali na Moravu (Lukačka 2010, 166). Zničenie daného mosta môže reflektovat' aj informácia z listiny uhorského panovníka Ladislava Pohrobka z roku 1453, ktorou potvrdil Mikulášovi Ilockému vlastníctvo panstiev Hlohovec a Tematín. Tu sa spomína právo na výnos z mýta v Hlohovci a brod na rieke Váh (MNL OL DL 14 726). Podl'a Štefana Dzura $(2017,97)$ bol tento prechod na mieste vyššie uvedeného zničeného mosta. O komunikačnom význame Hlohovca svedčí aj fakt, že sa tu vyberal tridsiatok (clo). Podl’a dokumentu z roku 1318 výnos z neho patril uhorským královnám (RDS1 II, 180 č. 369). Pramene z obdobia novoveku svedčia o tom, že v období od 17. do konca 19. storočia došlo k viacerým výstavbám alebo opravám mostu pri Hlohovci. Od 30. rokov 18. storočia tu existovali dokonca dva mosty, ktoré boli úplne zničené povodňou v júli 1781. Následne bol postavený len jeden most (Chrastina-Rácová 2015, 25-26; Chrastina-Rácová-Brůna 2015, 81; PišútProcházka-Matečný-Bandura 2016, 224-226). ${ }^{15}$ Veduta mesta Hlohovec z polovice 18. storočia zobrazuje drevený most na pilieroch (Zásady ochrany PZ Hlohovec), ktorý sa nachádza v tých istých miestach alebo blízko miesta dreveného mostu na pilieroch zobrazeného mape Prvého vojenského mapovania (Die Josephinische Landesaufnahme 1782-1785). Most sa na oboch zobrazeniach t’ahá od l’avého brehu Váhu na pravý, smerom na dnešné Šulekovo, čast' Hlohovca. Na vyššie spomenutej vedute sú povyše mosta zobrazené dva lodné mlyny ukotvené na pravom brehu Váhu, nižšie od nich sa plaví plt's dvomi pltníkmi, na l’avom brehu sa oproti spomínaným lodným mlynom nachádza jeden vodný mlyn, a potom poniže mosta alebo skôr hned' za ním je na l’avom brehu Váhu kotvisko pltí (Zásady ochrany PZ Hlohovec).

Z Hlohovca, dôležitého komunikačného uzla s mostom z obdobia vrcholného i neskorého stredoveku, pochádzajú nasledovné vodné nálezy. Z neznámej polohy v rámci Hlohovca alebo okolia poznáme jedno torzo meča približne datovatel'ného do 14. storočia (Labuda 2016, 119; Ruttkay 1975, 199, kat. č. IV). Žial’ tento nález sa nedá pevne stotožnit’ s riekou Váh. Z neznámej menšej vodnej plochy ned’aleko l'avého brehu Váhu bol iný meč vytiahnutý počas tažby štrku v roku 2000 (Labuda 2016, 62-64, obr. 43-47; Novosedlík 2002, 143, obr. 103), ktorý vieme zaradit' od polovice 14. do začiatku 15. storočia (Labuda 2016, 62). Z riečneho koryta Váhu bol vylovený i značne skorodovaný tesák, ktorý ostal čiastočne obalený i riečnymi okruhliakmi a dodnes nebol publikovaný (Urminský 2019). Danú zbraň môžeme zaradit' podl'a analógií do obdobia od druhej štvrtiny 15 . do prvej polovice 16. storočia. ${ }^{16}$ Okrem toho vieme, že z koryta Váhu pri Hlohovci, presnejšie ned’aleko jeho l’avého brehu, pochádzajú dôležité nálezy ôsmich medených koláčov, ktoré sú deponované v zbierkach Vlastivedného múzea v Hlohovci (Urminský 2018). Ich váha sa pohybuje od 2 do $5,72 \mathrm{~kg}$, ich priemer od 28 do $49 \mathrm{~cm}$ a hrúbka od 1,5 do $2 \mathrm{~cm}$. Spomenuté múzeum ich získalo v rokoch 2001 až 2017 a ich podobné chemické zloženie naznačuje, že by mohli byt' vyt'ažené v L'ubietovskom a Špaňodolinskom rudnom revíri. Tieto koláče, ako aj iné, dnes už nezvestné, sa začali od 90 . rokov 20. storočia objavovat' v štrkových nánosoch Váhu, v rozmedzí asi 80 metrov po prúde od dnes už zaniknutého cestného mosta cez Váh, ktorý existoval v druhej polovici 18. storočia v Hlohovci (Urminský 2019). V súčasnosti je z nich publikovaný iba jeden exemplár (priemer $42-45 \mathrm{~cm}$, výška $2 \mathrm{~cm}$, hmotnost' $5,72 \mathrm{~kg}$ ), ktorý sa našiel v roku 2001 na l'avom brehu Váhu pri Hlohovci (Novosedlík 2004, 253-256, obr.

15 Najstaršie koly dreveného mosta, ktorý stál v Hlohovci od 40. do začiatku 80. rokov 18. storočia, vieme zaradit' podl'a vykonaného dendrochronologického výskumu najskôr do 17. storočia (Pišút-Procházka-Matečný-Bandura 2016, 229, obr. 189; Urminský 2003). No tento most najpravdepodobnejšie nemá súvislost' so stredovekým premostením Váhu pri Hlohovci.

16 Jeho mierne zaoblenú zobákovitú hlavicu by sme mohli zaradit' k variantu F1 podl’a klasifikácie Petra Žákovského, týkajúcej sa moravských a sliezskych nálezov z Českej republiky. Tie sú väčšinou datované do druhej polovice 15. storočia, no pre všetky varianty typu F udáva spomenutý autor datovanie od druhej štvrtiny 15. do prvej polovice 16. storočia (Žákovský 2014, 316-317, obr. 268, 286, 288). V pol'skom Sliezsku takéto hlavice zaradil Lech Marek k typu D1, ktorý tu vymedzil koncom 15. a začiatkom 16. storočia (Marek 2008, 63, ryc. 76:a). Hlavice týchto tesákov poznáme hlavne zo strednej Európy vrátane Slovenska (Žákovský 2014, 316-317). Čepel' nami posudzovaného tesáka sa na Morave a Sliezsku (v rámci Českej republiky) dá stotožnit's typom B2 alebo B2a Petra Žákovského. Prvý z nich bol datovaný do priebehu 15. a začiatku 16. storočia a druhý najmä do druhej polovice 15. storočia (Žákovský 2014, 226-229, obr. 176-177). 
na s. 254; 2002a, 143-144, obr. 104). Vzhl'adom na rozmery a analógie sa daný koláč dá zaradit' do stredoveku i novoveku (Novosedlík 2004, 255). ${ }^{17}$ Do rovnakého obdobia a miesta tažby by sme mohli na základe vyššie uvedených skutočností zaradit' i ostatných sedem spomenutých medených koláčov. K vyššie spomínanému (stredovekému) prievozu medzi Červeníkom ${ }^{18}$ a Svätým Petrom, dnes už začleneným do Hlohovca, možno náleží čepel' meča objavená pri stavbe hydrocentrály na rieke Váh pri Červeníku, ktorú Michal Labuda podla analógií zaradil do prvej polovice 12. storočia (Labuda 2016, 60-61, obr. 41-42; Ruttkay 1975, 135, Abb. 2:1; 13:6). V roku 2017 bola v rieke Váh pri Koplotovciach (na l’avobreží Váhu, severne od Hlohovca) nájdená hlavica sekery s perforovaným listom s kolkovanou výzdobou, ako aj výrazným tylovým obuchom. ${ }^{19}$ K tejto lokalite sa ohl'adne prechodu Váhu neviažu písomné pramene a daná čast' zbrane môže byt’ na základe európskych i slovenských paralel datovaná do 14. až 16. storočia (Głosek 1996, 30-31, čakany, podtyp Ib, tabl. VII; VIII:1-2; Novotný 1965, 76, tab. XIV:6).

Pozoruhodný súbor vodných nálezov pochádza z vyššie po prúde situovaných Drahoviec-Bakovej, ktoré sa nachádzajú južne od Pieštan a podl'a písomných prameňov sa tu v posudzovanom období nenachádzal prechod. V neznámej polohe v extraviláne Drahoviec (pravdepodobne z Bakovej) bola pri t’ažbe štrku nájdená železná hlavica sekery (Klčo 1991, 50, obr. 14). Podl'a analogických exemplárov sa nazdávame, že ju môžeme zaradit' do 13.-16. storočia (Głosek 1996, 43-46, 80, tabl. XXIV:A, C, E, F; XXV:A, D, E; XXVI:A, C; XXVII:D, E; XXVIII:A, B; XXIX:A, B; Žákovský 2011, 156, obr. 8:6, tab. XI:3; 2015, 78, obr. 7; Ruttkay 1978, 106, obr. 30; 1985, 209, obr. 77:2; Ţiplic 2011, 86 [poznámka č. 65], 104, Pl. 5:4; Niṭoi 2007, 51, obrázok na strane 51). V roku 1988 sa v pôvodnom inundačnom území Váhu, medzi starým korytom Váhu a prívodným kanálom hydrocentrály v Maduniciach, našiel pri t’ažbe štrku Stanislavom Surovým hromadný nález bodno-sečných zbraní, konkrétne dva meče, štyri tesáky a jeden končiar (Labuda 2016, 30-31, 52-59, 104-114, obr. 27-40; 102-114; Klčo 2004, 194-199; Klčo-Krupa 2004, 39-41, obr. 2:1-3). Daný depot vieme zaradit' do prvej polovice 15. storočia (Krupa 2004, 197; Labuda 2016, 30-31). Poloha Baková v rámci obce Drahovce je dnes zhruba medzi Drahovským kanálom a riekou Váh, a teda svojím spôsobom medzi obcou Sokolovce a Drahovce. Počas vytvárania Prvého vojenského mapovania bola medzi tými dvoma obcami kompa cez Váh, do ktorej vyústovali cestné komunikácie z oboch obcí (Die Josephinische Landesaufnahme 1782-1785). Na l’avom brehu Váhu, v riečnom meandri, ktorý bol z východnej strany Bakovej, sa na spomínanom mapovaní nachádzal vodný mlyn. Marián Klčo $(2004,197)$ spomenul, že v miestach dnešnej polohy Baková existovala pôvodne dedina Baková (Bakó), ktorá zanikla po opakujúcich sa povodniach v druhej polovici 18. storočia. V Pamätnej knihe obce Drahovce sa uvádzajú nálezy zbraní (šable a dýky) v náplavách Váhu a intraviláne obce, ktoré boli považované za turecké. No nie je vylúčené, že mohlo íst' aj o stredoveké zbrane (Klčo 2004, 197).

Severne od Hlohovca existoval významný prechod cez rieku Váh v Pieštanoch (Pestyen). Od roku 1348 vlastnil panstvo Tematín, spolu s Pieštanmi, Mikuláš Kont, zakladatel' rodu Ilockých (Lukačka 1993-1994, 102). Platenie mýta sa spomína až v roku 1424. Oslobodení od poplatku boli pocestní, ktorí prechádzali z Beckova (Bolondoch) do Nitrianskej Blatnice (Serfew; ZSO IX, 539 č. 1348). Ilockí dali v roku 1435 do zálohu so súhlasom panovníka celé Pieštany spolu s brodom cez Váh a mýtnou stanicou za 129 zlatých Michalovi a Ondrejovi, synom Imricha z Očkova (Lukačka 1993-1994, 104). V roku 1453 Pieštany s mýtom vlastnil už opät' Mikuláš Ilocký (MNL OL DL 14726). V roku 1489 mal byt’ Juraj Požar z Marcelovej uvedený do vlastníctva celého majetku Pieštany (Pesthyen) aj spolu s mýtom a polovicou majetku Horná Streda (Zerdahel), ale proti tomu vystúpili v mene Vavrinca Ilockého kasteláni hlohoveckého hradu (FRS

17 Analógie, ktoré v preberanom období mali svoj priemer medzi 20 až $60 \mathrm{~cm}$, pochádzajú z morského dna južne od Helgolandu (Nemecko, datovanie do rokov 1140-1340), z vraku potopenej lode s 3 tonami podobných koláčov z Gdanska (Pol'sko, datovanie do roku 1380) a z rieky Labe medzi Wittenbergom a Hamburgom (Nemecko, datovanie do 15.-16. storočia), ktoré mali dokonca pôvod v okolí Banskej Bystrice (Novosedlík 2004, 254-255). Praveké exempláre z eneolitu a doby bronzovej zo Slovenska a Mad’arska mali rozmery len medzi 10,8 až 30 cm (Novosedlík 2004, 254).

18 Pôvodná obec bola na území dnešného Leopoldova (Labuda 2016, 60).

19 Za informáciu o tomto náleze, ako aj možnost' ho zdokumentovat', d'akujeme Mgr. Jozefovi Urminskému, riaditel'ovi Vlastivedného múzea v Hlohovci. 
IV, 273-274 č. 227; 274-275 č. 228). O význame prechodu svedčí aj existencia starého mýta na druhej strane Váhu v Banke. Tu existovalo mýto, z ktorého desatinu výnosov získal v roku 1270 od uhorského krála Bela IV. nitriansky biskup Vavrinec (CDP VII, 125 č. 94). Výnosy z neho si privlastnil na začiatku 14. storočia Matúš Čák, ako o tom svedčí st’ažnost' Nitrianskeho biskupstva z roku 1318 (RDSI II, 152 č. 312). V roku 1453 výnosy z mýta patrili už Mikulášovi Ilockému (MNL OL DL 14726).

Význam brodu v priestore Pieštan vo vrcholnom a neskorom stredoveku je zvýraznený i príslušnými vodnými nálezmi. Popri nejasnom datovaní hrotu kopije/oštepu, ${ }^{20}$ ktorý bol nájdený spolu (najpravdepodobnejšie) so včasnostredovekou hlavicou sekery v roku 1965 pri bagrovaní koryta Váhu pri Pieštanoch (Ruttkay 1975, 167, kat. č. 119, Abb. 20:12), tu máme iné dva vodné nálezy hrotov kopijí/oštepov z rovnakej rieky. Prvý hrot (Klčo-Krupa 2004, 42, obr. 3:10), opatrený relatívne úzkym trojuholníkovým listom s najväčšou šírkou v spodnej časti (s prítomnými relatívne ostrými zlomovými uhlami ostria), tesne nad kŕčkom hrotu, a tulajkou rozširujúcou sa $\mathrm{k}$ ústiu. List je v prípade tohto hrotu dlhší než tulajka. Zdá sa, že na liste nie je prítomné výrazné stredové rebro a hrot nemá inú úpravu, či už plastickú, alebo aplikovanie tauzie a inkrustácie. Tým pádom ho môžeme datovat' podl’a európskych paralel od 10. do 14. až 15. storočia. ${ }^{21}$ Druhý vyššie spomenutý hrot (Klčo-Krupa 2004, 42, obr. 3:8), ktorý má elipsovitý tvar listu / jeho list má tvar vŕbového listu, je možné datovat' iba široko - od staršej doby železnej až po 13. storočie (Husár 2014, 46-48, obr. 3; Ruttkay 1976, 300, Abb. 36: Typus II). Posledný vodný nález týkajúci sa Piešt’an predstavuje torzo meča nájdeného počas t’ažby štrku v inundácii Váhu, na jeho úseku medzi Pieštanmi a Moravanmi nad Váhom (Klčo-Krupa 1994, 19, obr. 3; 2004, 39, obr. 1:3; Labuda 2016, 49-51, obr. 23-26), ktorý sa dá typologicky začlenit' do poslednej štvrtiny 14. až začiatku 15. storočia (Labuda 2016, 49). Nálezy najskôr súvisia s vyššie spomínaným brodom. Taktiež vieme, že na juh od Piešt'an sa podl'a Prvého vojenského mapovania mohol nachádzat' i prievoz. Z neho sa dalo potom preplavit' na Banku. Lokalizáciu brodu môže tiež pomôct' osvetlit' vyššie spomínané mapovanie. Podl'a neho ho vieme umiestnit' medzi Piešt’any a Moravany nad Váhom, kde sa nachádzali v druhej polovici 18. storočia i tri lodné mlyny (Die Josephinische Landesaufnahme 1782-1785).

Na sever od Pieštan, v blízkosti Bašoviec, existoval v sledovanom období prístav v dnes už zaniknutej dedine Lubov, ktorý je doložený v roku 1263 (PSZBRT II, 322 č. 57). Tu sa dalo prejst' na druhú stranu Váhu do Ducového, o čom svedčí v prameňoch uvádzaný miestny názov Ducrév. ${ }^{22} \mathrm{Na}$ začiatku 14. storočia Lubov s prístavom držal vo svojom vlastníctve Matúš Č́k. Svedčia o tom st’ažnosti z rokov 1317 a 1321 (PSZBRT II, 605). Situáciu na sever od Ducového nám osvetl'uje revízia mýtnych staníc z roku 1424, kde je zmienka o starom prievoze pri dedine Hrádok (Hradnok; ZSO IX, 539 č. 1348).

Z koryta Váhu z vyššie spomenutých troch obcí sa žiadny vodný nález na povrch nedostal, no zato ich poznáme z l'avobrežnej inundácie Váhu pri Hubine-Závaží a z Vážskeho kanála i Vážskej kaskády pri Hornej Strede. Pri t’ažbe štrku v pôvodnej l’avobrežnej inundácii rieky Váh pri Hubine-Závaží sa našla železná hlavica sekery s vbíjanou značkou v tvare štvorlístka (Klčo

20 Nepoznáme jeho vyobrazenie, no možno ide o hrot, ktorý preberáme v nasledujúcich riadkoch (Klčo-Krupa 2004, 42, obr. 3:10) a miesto jeho uloženia je Balneologické múzeum v Pieštanoch.

21 Hranato profilované hroty kopiji/oštepov, často pravdepodobne aj s výrazne vystupujúcim rebrom, sa objavili už v dobe železnej - skýtskom prostredí 7. až 6. storočia pred n.l. (Petrenko 1995, 14, Fig. 8:d). Rovnako tomu bolo aj počas obdobia principátu na území Rímskej ríše (Bishop-Coulston 2006, Fig. 38:13) a pravdepodobne tento trend môžeme na ríšskom území potvrdit' aj pre obdobie dominátu (Gudea 2010, Abb. 3:L5.). V Karpatskej kotline sa s najväčšou pravdepodobnost'ou začali objavovat' hroty s relatívne dlhším trojuholníkovým listom (avšak bez výrazného stredového rebra) s najväčšou šírkou tesne nad kŕčkom hrotu a ostrými zlomovými uhlami ostria už od druhej polovice 8 . storočia (hrot z hrobu zo Söjtör) či od obdobia okolo roku 800 (hrot z depotu z Gajár - Pustatiny Vrablicovej II; Husár 2014, 62, 118, 121, tabela 1; tab. XLVI:5; XLVIII:7). Šírka ich listu či pomer medzi dížkou listu a tulajky sa však nezhoduje s nami posudzovaným hrotom. Hroty profilované podobne ako nami skúmaný exemplár nachádzame však v Pol’sku v 11. a na počiatku 12. storočia (Nadolski 1954, Tabl. XXI:1, 3, 4; Strzyż 2006, Tabela VIII: Nr. Kat. 21; ryc. 12:10), možno na Slovensku i v Európe v 12. a 13. storočí (Ruttkay 1976, 301; v Európe v danom období prichádza k zhrubnutiu, zašpicateniu hrotov kopiji/oštepov a zväčšeniu otvorov v tulajkách), na Rusi medzi 10. až 12. storočím niektoré z hrotov typu III A. Н. Кирпичникова (1966, 72 [каталог], 82 [каталог], 84 [каталог], табл. III:6-7; IV:3, 8; V:13; VII:10, 11, 13) a v Čechách a na Morave ešte v 14. až 15. storočí (exempláre s nie príliš výrazným stredovým rebrom; Žákovský 2008, 480, obr. 3:2, 4-6; 4:3, 6-8).

22 V roku 1348 sa spomína Duchreuy (MNL OL DL 71416), roku 1453 Dwcrew (MNL OL DL 14726) a v roku 1524 Dechobrod (MNL OL DL 71531). Mad’arské slovo rév indikuje plytčinu, brod, prievoz alebo prístav (Arcanum Kézikönyvtár). Nakol'ko v neskoršom období (16. storočie) máme doložený slovenský termín brod $\mathrm{v}$ súvislosti s Ducovým, nazdávame sa, že staršie záznamy sa najpravdepodobnejšie museli viazat' iba na miestny brod cez rieku Váh. 
1988, 76, obr. 16). Na základe relevantných paralel, týkajúcich s aj vbitej značky, ju môžeme zaradit' do 14.-16. storočia (Głosek 1996, 88, 90-92; nr kat. 64; 91; 115; tabl. XIX:E; XX:G; XXI:C; Novotný 1956, 346). Z mapy Prvého vojenského mapovania môžeme dedukovat', že minimálne v druhej polovici 18. storočia pretekalo polohou Závažie jedno z ramien Váhu (Die Josephinische Landesaufnahme 1782-1785). Nálezisko sa však nachádza $270 \mathrm{~m}$ juhozápadne od kóty 164, čo je tiež blízko k hlavnému korytu Váhu. Daná lokalita má i blízko k Ducovému, kde bol v skúmanom období prechod Váhu. Z prác na regulácii Váhu pri Hornej strede boli v 50. rokoch 20. storočia nájdené robotníkmi rôzne (najpravdepodobnejšie) včasnostredoveké predmety, ako hlavica sekery (bradatica), tri články (koráliky) z náhrdelníka a silne skorodovaný hrot kopije/ oštepu (Nálezová správa AÚ SAV č. 601/55 [evidovaná v nasledujúcej literatúre nesprávne aj pod č. 3322/55 - Vendtová 1964, 162; Ruttkay 1975, 144]). Spomenutý hrot kopije/oštepu má podla ilustrácie v Nálezovej správe AÚ SAV č. 601/55 list tvaru vŕbového listu, respektíve elipsovitý tvar listu, a preto ho môžeme datovat' len do širšieho časového úseku začínajúceho v staršej dobe železnej a končiaceho v 13. storočí (Husár 2014, 46-48, obr. 3; Ruttkay 1976, 300, Abb. 36: Typus II). Ďalej vieme, popri bližšie nešpecifikovanom „gotickom meči“, aj o jednom tesáku vybagrovanom v inundácii Váhu počas stavby III. stupňa Vážskej kaskády na 38,5. kilometri pri Hornej Strede (Nálezová správa AÚ SAV č. 601/55; Labuda 2016, 102-103, obr. 100-101; Klčo-Krupa 2004, 41, obr. 2:4). Daný tesák môžeme zaradit' do obdobia začiatku 15. až začiatku 16. storočia (Labuda 2016, 102). Z 38,425. kilometra Vážskeho kanála, v inundácii Váhu pri Hornej Strede, bol vybagrovaný meč (Labuda 2016, 46-48, obr. 20-22; Klčo-Krupa 1994, 20-22, obr. 4; 2004, 39, obr. 1:5), ktorého datovanie spadá do poslednej štvrtiny 14. až začiatku 15. storočia (Labuda 2016, 46).

V blízkosti prievozu pri dedine Hrádok existoval na pravom brehu Váhu prístav v Novom Meste nad Váhom (Vyhel, que alio nomine Regia Villa), o ktorom je zmienka v listine z roku 1263 (PSZBRT II, 322 č. 57) V roku 1388 Žigmund Luxemburský daroval Beckovské hradné panstvo aj s novomestským mýtom významnému šlachticovi Stiborovi zo Stiboríc (MNL OL DL 7414; Wenzel 1874, 49-51). Po smrti jeho syna daroval v roku 1437 panovník panstvo do dedičnej držby spolu s Novým Mestom nad Váhom (oppidum Wyhel et thelonei) Pavlovi Bánfimu (MNL OL DF 211034). V urbári Beckovského panstva z roku 1522 sa uvádza novomestský prievozník Gregor (Marsina-Kušík 1959, 53). V Novom Meste nad Váhom sa vyberal aj tridsiatok. V roku 1454 uhorský panovník Ladislav V. (1440/1453-1457) dal tunajšiu tridsiatkovú stanicu do prenájmu na dvanást' rokov mestu Bratislava (Lehotská 1956, 409, č. 2977). Na l'avom brehu Váhu je v roku 1321 doložená mýtna stanica v Kočovciach (Huchk et Huchk; RDS1 II, 306 č. 678) a roku 1437 sa ako súčast' majetkov hradného panstva Beckov uvádza d’alšia mýtnica v ned’alekej Novej Vsi nad Váhom (Wyfalw; MNL DF 211034). O nej je tiež zmienka v urbári Beckovského panstva z roku 1522 (Marsina-Kušík 1959, 45).

Z vyššie uvedených lokalít sa vodné nálezy týkajú len Novej Vsi nad Váhom. V polohe Políčko, do ktorého zasahuje dial'nica D-1 v jej kilometri 86,8 a 87,2, sa v roku 1975 našli dva črepy z 11. až 12. storočia (Bialieková ed. 1989a, 392). Táto poloha a tadial' prebiehajúca dial'nica D-1 bola podl’a Prvého vojenského mapovania blízko jedného z ramien Váhu (Die Josephinische Landesaufnahme 1782-1785). Vel'mi blízko Nového Mesta nad Váhom, kde sa v posudzovanom období vyberalo mýto, je katastrálne územie Kočoviec, ktoré sa tiež dotýka koryta Váhu a rovnako sa na ňom vyberalo i mýto. V roku 1911 (11 ks) a 1931 (2 ks) sa tu našlo spolu 13 medených koláčov pri l’avom brehu koryta rieky Váh, kde sa pri vel'mi malej vode nakladal piesok na vozy. K. Brancsik, hlavný župný lekár a zakladatel' múzea v Trenčíne, zachránil z celkového množstva nájdených medených koláčov len jeden z nich (Mádl 1936, 110-111, obr. 1a, 1b; Novosedlík 2004, 253). Dodnes je tento koláč v zbierkach Trenčianskeho múzea v Trenčíne a jeho priemer je 45-47 cm (Mádl 1936, 110-111, obr. 1a, 1b; Novosedlík 2004, 253). Medený koláč môžeme podl'a rozmerov, ako som už uviedol vyššie pri (publikovanom) skoro rovnakom exemplári z koryta Váhu pri Hlohovci, datovat’ do stredoveku a novoveku (Novosedlík 2004, 255). Zaujímavou informáciou je, že pod vrchom Inovec v pohorí Považský Inovec, východne od Kočoviec a pri dnešnej obci Selec, sa v minulosti t’ažila med' (Mádl 1936, 111). Vrch Inovec (1042 m n.m.) je 


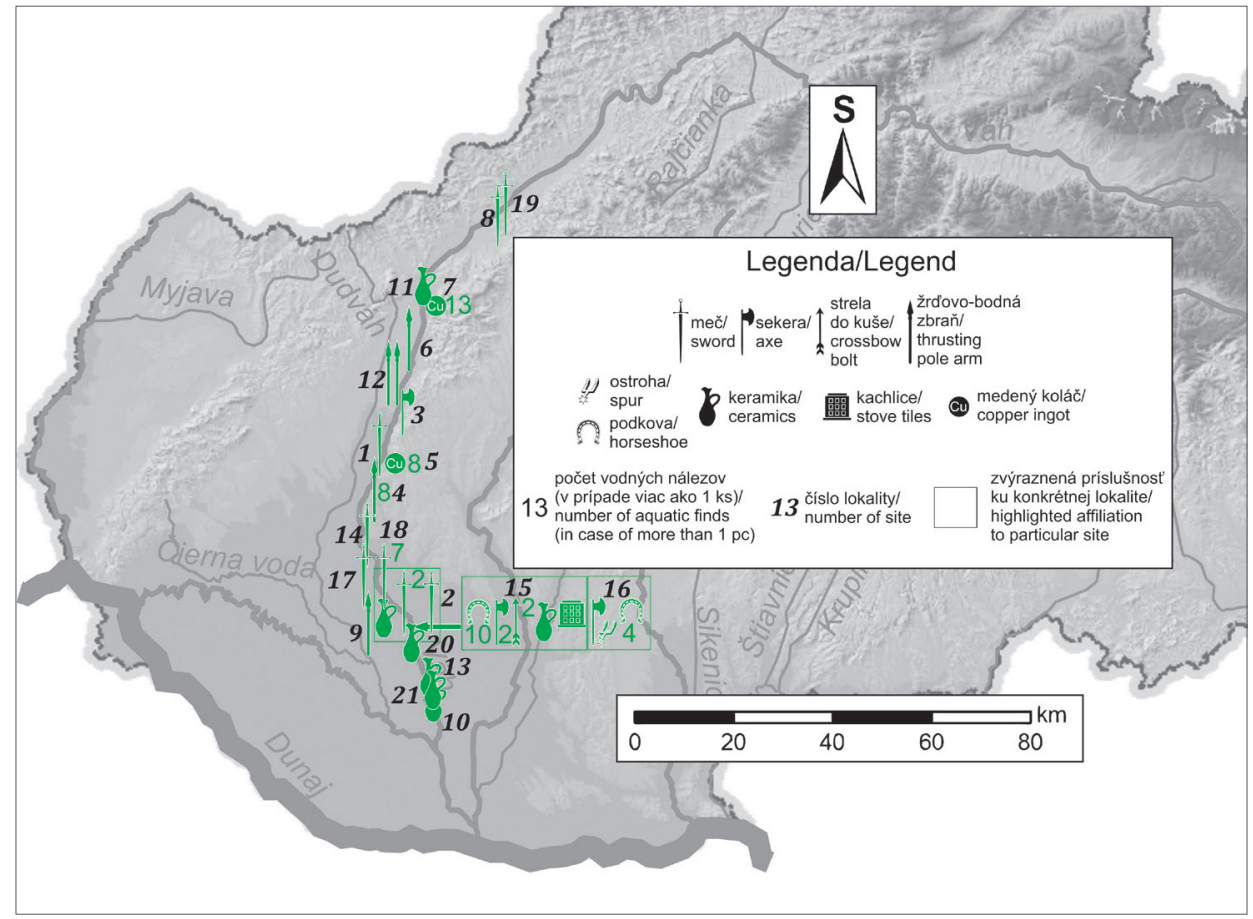

Obr. 3. Vodné nálezy z dolného a stredného Považia vo vrcholnom stredoveku, druhá polovica 11. storočia - 13. storočie. Archeologické lokality: 1 - Červeník; 2 - Dlhá nad Váhom; 3 - Drahovce; 4 - Dvorníky-Posádka / Berek; 5 - Hlohovec; 6 - Horná Streda; 7 - Kočovce; 8 - Kostolná-Záriečie; 9 - Král’ová nad Váhom; 10 - Neded - koryto Váhu na 37.-38. riečnom km; 11 - Nová Ves nad Váhom - Políčko; 12 - Piešt’any; 13 - Selice - koryto Váhu na 45.-47. riečnom km; 14 - Sered' - Hrad Šintava; 15 - Šal’a - kory to Váhu na 55.-59. riečnom km; 16 - Šal’a - koryto Váhu na 56. riečnom km; 17 - Šoporňa-Pasienok; 18 - Šoporňa-Štrkovec - Galantská sihot'; 19 - Trenčín - koryto Váhu pri moste na Ostrov; 20 - Trnovec nad Váhom - koryto Váhu na 52. riečnom km; 21 - Vlčany - koryto Váhu na 41. riečnom km.

Abb. 3. Wasserfunde aus dem unteren und mittleren Waag-Gebiet im Hochmittelalter, zweite Hälfte 11. Jhdt.- 13. Jhdt. Archäologische Fundstellen: 1 - Červeník; 2 - Dlhá nad Váhom; 3 - Drahovce; 4 - Dvorníky-Posádka / Berek; 5 - Hlohovec; 6 - Horná Streda; 7 - Kočovce; 8 - Kostolná-Záriečie; 9 - Král’ová nad Váhom; 10 - Neded - Flussbett der Waag am 37.-38. Flusskilometer; 11 - Nová Ves nad Váhom - Políčko; 12 - Piešt’any; 13 - Selice - Flussbett der Waag am 45.-47. Flusskilometer; 14 - Sered' - Hrad Šintava; 15 - Šal'a - Flussbett der Waag am 55.-59. Flusskilometer; 16 - Šal'a - Flussbett der Waag am 56. Flusskilometer; 17 - Šoporňa-Pasienok; 18 - Šoporňa-Štrkovec-Galantská sihot’; 19 - Trenčín - Flussbett der Waag bei der Brücke zur Flussinsel; 20 - Trnovec nad Váhom - Flussbett der Waag am 52. Flusskilometer; 21 - Vlčany Flussbett der Waag am 41. Flusskilometer.

vzdialený od Váhu pri dnešných Kočovciach 12 až 14,5 km vzdušnou čiarou. Dôležitým faktom je i to, že podl’a Prvého vojenského mapovania prechádzala cesta od Kočoviec cez štyri ramená Váhu do Nového Mesta nad Váhom, a to pomocou štyroch brodov (Die Josephinische Landesaufnahme 1782-1785).

V roku 1291 sa spomína prístav na rieke Váh pri Trenčíne. Na tretinu z výnosu poplatkov malo nárok Nitrianske biskupstvo (CDH VII/2, 151 č. 405). V Trenčíne (Trenchen) sa spomína konkrétne vyberanie mýta až v súvislosti s rokom 1321 (RDSl II, 303 č. 673). Zmienka o tunajšom moste cez rieku Váh je však staršia. V roku 1116 prebiehal vojenský konflikt uhorského krála Štefana II. a českého panovníka Vladislava I. V tretej knihe Kroniky Čechov od Kosmasa je údaj z roku 1116 o vojenskom tábore v blízkosti Belinho mostu (ultra pontem Belin) na rieke Váh. Práve existencia tohto mostu sa spája s Trenčínom (Kosmas 2011, 182, 246). V roku 1379 uhorský král' L'udovít I. nariadil, aby Trenčania mohli slobodne t’ažit' drevo, ktoré potrebujú na opravu mosta cez Váh, poškodeného l'adom a povodňou (Karlík 2013). Listina z roku 1402, 


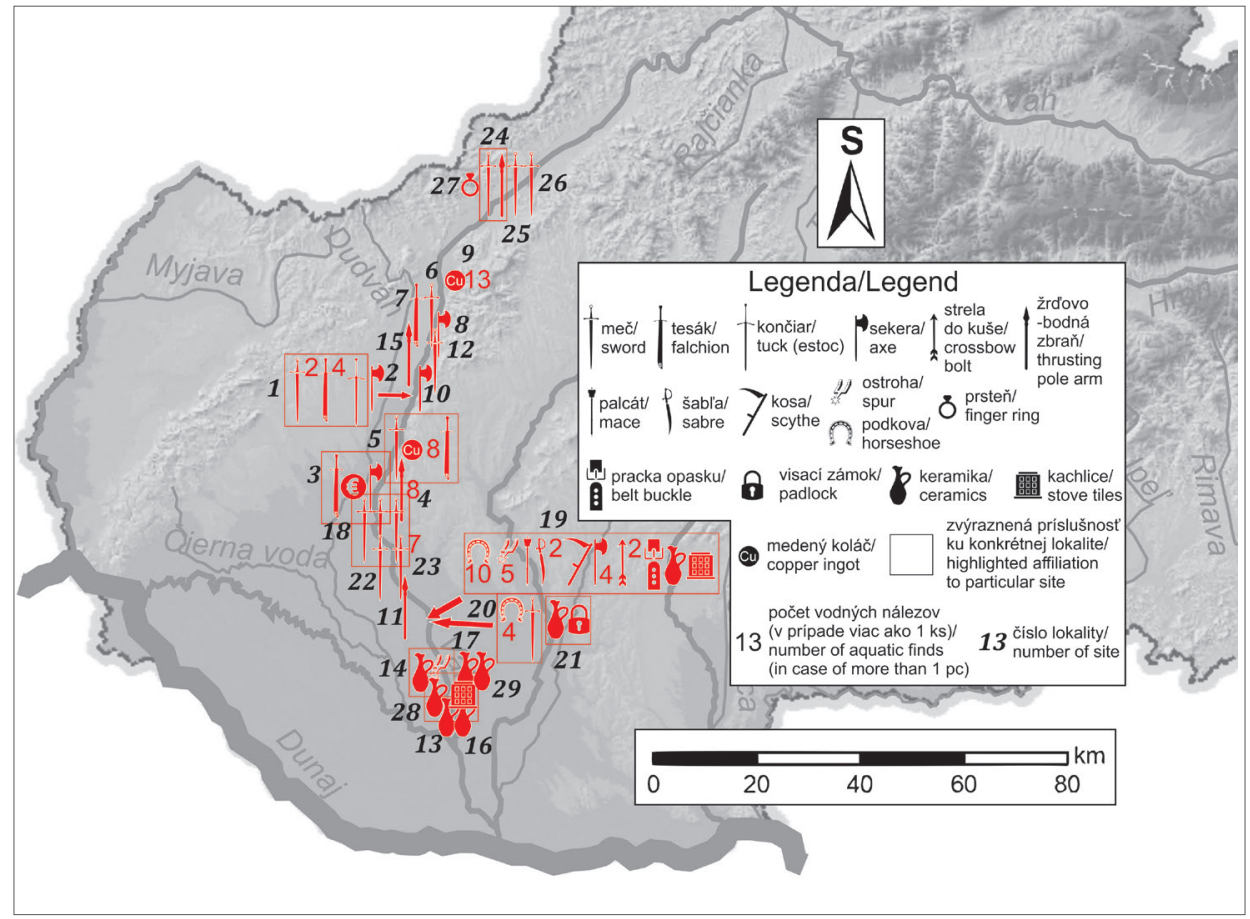

Obr. 4. Vodné nálezy z dolného a stredného Považia v neskorom stredoveku, 14. storočie - prvá polovica 16. storočia. Archeologické lokality: 1 - Drahovce-Baková; 2 - Drahovce - neznáma poloha; 3 - Dvorníky-Červeníky; 4 - Dvorníky-Posádka / Berek; 5 - Hlohovec; 6 - Horná Streda - Vážsky kanál; 7 - Horná Streda - Vážska kaskáda; 8 - Hubina-Závažie; 9 - Kočovce; 10 - Koplotovce; 11 - Král'ová nad Váhom; 12 - Moravany nad Váhom / Piešt’any; 13 - Neded - koryto Váhu na 37.-38. riečnom km; 14 - Neded - rameno Váhu v obci; 15 - Piešt’any; 16 - Selice - koryto Váhu na 45. -47. riečnom km; 17 - Selice - Váh na 43. riečnom km; 18 - Sered' - Hrad Šintava; 19 - Šal'a - koryto Váhu na 55. -59. riečnom km; 20 - Šal'a koryto Váhu na 56. riečnom km; 21 - Šal’a-Veča - mŕtve rameno Váhu; 22 - Šoporňa-Pasienok; 23 - Šoporňa-Štrkovec Galantská sihot'; 24 - Trenčín - koryto Váhu; 25 - Trenčín - koryto Váhu pri moste na Ostrov; 26 - Trenčín-Orechové; 27 - Trenčín-Záblatie; 28 - Vlčany - koryto Váhu na 41. riečnom km; 29 - Vodné dielo Selice.

Abb. 4. Wasserfunde vom unteren und mittleren Waag-Gebiet im Spätmittelalter, 14. Jhdt.- erste Hälfte 16. Jhdt. Archäologische Fundstellen: 1 - Drahovce-Baková; 2 - Drahovce - unbekannte Lage; 3 - Dvorníky-Červeníky; 4 - Dvorníky-Posádka / Berek; 5 - Hlohovec; 6 - Horná Streda - Waag-Kanal; 7 - Horná Streda - Waag-Kaskade; 8 - Hubina-Závažie; 9 Kočovce; 10 - Koplotovce; 11 - Král’ová nad Váhom; 12 - Moravany nad Váhom / Piešt’any; 13 - Neded - Flussbett der Waag am 37.-38. Flusskilometer; 14 - Neded - Flussarm der Waag in der Gemeinde; 15 - Piešt'any; 16 - Selice - Flussbett der Waag am 45.-47. Flusskilometer; 17 - Selice - Waag am 43. Flusskilometer; 18 - Sered' - Hrad Šintava; 19 - Šal'a - Flussbett der Waag am 55.-59. Flusskilometer; 20 - Šal'a - Flussbett der Waag am 56. Flusskilometer; 21 - Šal'a-Veča - Toter Arm der Waag; 22 - Šoporňa-Pasienok; 23 - Šoporňa-Štrkovec - Galantská sihot'; 24 - Trenčín - Flussbett der Waag; 25 - Trenčín Flussbett der Waag an der Brücke zur Flussinsel; 26 - Trenčín-Orechové; 27 - Trenčín-Záblatie; 28 - Vlčany - Flussbett der Waag am 41. Flusskilometer; 29 - Wasserkraftwerk Selice.

ktorú vydal Žigmund Luxemburský, obsahuje najstarší súbor práv a výsad obyvatel’ov Trenčína. V nej je uvedené, že každý, kto prejde s tovarom na predaj po mestskom moste (cez Váh), musí pri príchode aj odchode zaplatit' mýto, ktoré bolo učené na jeho opravu (MNL OL DF 280008; Marsina 2010, 513). Ďalšie mýto sa vyberalo v dnešnej Kostolnej-Záriečí (Dregma). Výnosy z neho dostávalo aj Nitrianske biskupstvo, o čom svedčí st’ažnost' z roku 1318, v ktorej sa píše, že Matúš Č́a Trenčiansky si ich privlastnil (RDS1 II, 152 č. 312).

Pri prehlbovaní koryta Biskupického (derivačného) kanála Váhu pri Trenčíne bol v roku 1948 objavený meč v obci Kostolná-Záriečie, v jej časti Kostolná (Labuda 2016, 42-45, obr. 15-19; Ruttkay 1975, 148-150, Abb. 5:2; 12:3). Jeho datovanie spadá na koniec 12. a začiatok 13. storočia (Labuda 2016, 42). Zo samotného Trenčína, kde písomné pramene dokladajú 
existenciu mosta a vyberanie mýta, máme z koryta Váhu alebo pravdepodobne z neho, viacero nálezov - a to najmä bodno-sečných zbraní. Dva meče, ktorých datovanie do vrcholného a neskorého stredoveku môžeme len tušit' z ich opisu, sa našli na neznámom mieste koryta Váhu v roku 1956 (Pozdišovský 1956, 11-12) a v súčasnosti nie sú pravdepodobne už k dispozícii. Príslušnost' d'alších dvoch mečov (Labuda 2016, 36-41, obr. 6-14; Ruttkay 1975, 208, kat. č. 8, Abb. 5:6; 14:3) a dvoch tesákov (Labuda 2016, 97-101, obr. 95-99) k vodným nálezom z rieky Váh, ktoré sú uložené v Trenčianskom múzeu v Trenčíne, je otázna. Tieto predmety môžeme datovat' od polovice 14. storočia do začiatku 16. storočia (Labuda 2016, 36, 39, 97, 99). Rovnako nemôžeme vôbec s istotou potvrdit', že tesák nájdený v Trenčíne-Biskupiciach pochádzal z koryta Váhu (Labuda 2016, 93-96, obr. 93-94). Môžeme ho zaradit' do záveru 15. až začiatku 16. storočia (Labuda 2016, 93). Posledné dva meče už môžeme spájat's korytom Váhu i s konkrétnym katastrálnym územím súčasného Trenčína. Jeden z nich bol nájdený v roku 1956 pri bagrovaní koryta Váhu, konkrétne v blízkosti mosta spájajúceho Trenčín s Ostrovom, a bol datovaný do 13.-14. storočia (Bialeková ed. 1989a, 416). Druhý meč sa našiel tiež v roku 1956 pri bagrovaní na pravom brehu koryta Váhu (pod železničným mostom), v Orechovom (Bialeková ed. 1989a, 417; Labuda 2016, 32-35, obr. 1-5; Pozdišovský 1956, 12; Ruttkay 1975, 182, kat. č. 163, Abb. 5:7; 15:4). Môžeme ho časovo zaradit' od druhej polovice 14. do začiatku 15. storočia (Labuda 2016, 32). Na neznámom úseku rieky Váh pri Trenčíne sa našiel i hrot kopije s dlhým trojuholníkovým listom a kratšou tulajkou s kruhovým prierezom (Ruttkay 1975, 182, Abb. 17:10). List hrotu je širší než priemer tulajky a na ňom boli aplikované z jeho oboch strán po dve menšie obdĺžnikové platničky z medi s rytou výzdobou (jedna z platničiek v súčasnosti chýba). Uvedený hrot sa na základe analógií dá datovat' do 15. až 16. storočia (Žákovský 2008, 473-482; Knific-Nabergoj 2017, 132, Fig. 161). Nakoniec posledný nález z koryta Váhu bol identifikovaný v Trenčíne-Záblatí. Pred rokom 1914 bol v miestnom štrkovisku pri obci na pravom brehu Váhu objavený bronzový štítkový prsteň. Nálezca (doktor Drucker) ho daroval múzeu v Trenčíne. Je na ňom vyrytý krížik a ostatné ryté časti výzdoby vytvárajú náznakovo rozetu alebo štvorcípu hviezdu (Bialeková ed. 1989a, 419; Brancsik 1914, 25, Таb. I:5, 5a). Игор Ђуровић (2012, 96-97, obr. na s. 96) jeden takýto prsteň z Národného múzea v Kragujevaci (neznáme miesto nálezu z roku 1997) datoval do 14.-16. storočia.

Drevený most cez Váh je zobrazený pri Trenčíne s hradbami aj na najstaršej panoráme mesta z rokov 1550-1575 (Plaček-Bóna 2007, 309, obr. 413; Slovenské hrady 2018). Rovnakú polohu a smer má i drevený most cez Váh pri Trenčíne, zachytený na mape Prvého vojenského mapovania. Cesta z neho smeruje na Žabinec, pred ktorým prekračuje dve ramená Váhu pomocou dvoch drevených mostov a cesta z neho potom vedie na Orechové (Die Josephinische Landesaufnahme 1782-1785). Nález meča z koryta Váhu pri moste na Ostrov sa dá možno osvetlit' aj situáciou v tejto oblasti zobrazenej na Prvom vojenskom mapovaní. V tomto priestore sú zakreslené štyri drevené mosty cez rameno Váhu a priekopy i cesta z Trenčína potom schádza týmto smerom na Kubrú. Miesto nálezu bronzové štítkového prsteňa v Záblatí sa dá do určitej miery objasnit’ tiež pomocou Prvého vojenského mapovania. Popri pravom brehu Váhu boli na danom mapovaní dva vodné mlyny a východne od Záblatia cez jedno z ramien Váhu prechádzal brod, z ktorého vychádzala cesta smerom na Trenčín (Die Josephinische Landesaufnahme 1782-1785).

\section{Pokus o vysvetlenie vodných nálezov z vrcholného a neskorého stredoveku v rieke Váh}

V nasledujúcich riadkoch budeme pojednávat' o interpretačných možnostiach preberaných vodných nálezov vo vzt’ahu k vyššie spomenutým prechodom cez Váh.

V kontexte doterajšieho relevantného vedeckého výskumu (napr. Anders-Gringmuth-Dallmer, 2015, 18; Vích 2016, 62) môžeme konštatovat', že pre dopravu by mohli byt' zo spomenutých nálezov smerodajnými podkovy ${ }^{23}$ a ostrohy, ${ }^{24}$ pre obchod (ale aj dopravu) to mohli byt' mince, ${ }^{25}$

23 Lokalita Šal'a - koryto Váhu na 55.-59. riečnom km; Šal’a - koryto Váhu na 56. riečnom km.

24 Lokalita Selice - koryto Váhu na 45.-47. riečnom km; Šal'a - koryto Váhu na 55.-59. riečnom km.

25 Lokalita Dvorníky-Červeníky. 
medené koláče ${ }^{26}$ či aj keramika, ${ }^{27}$ ak samozrejme pri nej nešlo o jej odplavenie alebo pôvodnú príslušnost' k nejakému sídlisku alebo pohrebisku.

Pri určitých udalostiach sa mohli predmety stratit' náhodne, alebo tomu tak bolo počas bojovej akcie. Niektoré vyššie spomenuté nálezy sekier, vhodné na opracovanie dreva ${ }^{28}$ a zaraditel'né do 8./11. až 16. storočia, sa mohli využivat' i pri opravách mostov, pričom sa mohli samozrejme i stratit'. Popri analógiách z archeologických prameňov existujú aj ikonografické pramene potvrdzujúce ich drevoobrábaciu funkciu. Napríklad ide o ilustrácie z diela Codex Cursus Sanctae Mariae z rokov 1200-1230 (Kláštor Louky, Česká republika; Husa-Petráň-Šubrtová 1967, obr. 85) a Biblie českého krála Václava IV. z rokov 1389-1400 (Husa-Petráň-Šubrtová 1967, obr. 86).

Ako príklad pre vodné nálezy z bojových akcií počas sledovaného obdobia môže poslúžit' potopenie sa mobiliára a pokladov s častou skupiny lodí královského dvora Ludovíta II. Jagelovského (1516-1526) v Dunaji pri Ostrihome. To sa udialo počas úniku jeho vdovy, královnej Márie, z Budína roku 1526 po tom, ako boli jej lode (66 ks) napadnuté (Tóth 2009, 412, 417).

V súvislosti s ostatnými predmetmi môžeme predpokladat’ však už väčšinou intencionálne deponovanie. Pri mečoch alebo iných honosných zbraniach a predmetoch mohla byt' v hre aj ich desakralizácia alebo odstránenie/zničenie po splnení ich účelu, napríklad po skončení aktívnej služby ich majitel'a, väčšinou aristokrata. Tak tomu bolo aj v prípade legendárneho návratu meča Excalibur prostredníctvom jedného z Artušových rytierov k Panej Jazera z dôvodu, že už splnil účel, a aby sa nedostal do rúk prípadným nehodným následníkom (Clark 2013, 14; Michalak 2012, 289, 314; Stocker-Everson 2003, 283). V rámci skúmaného súboru sa meče našli na viacerých úsekoch sledovaného povodia Váhu. ${ }^{29}$ Marian Głosek $(1984,19)$ v rámci svojho výskumu uviedol, že $50 \%$ nálezov mečov z 10. až 15. storočia v strednej Európe pochádza z vodných plôch, kým Ewart Oakeshott (1991, 3) zase tvrdil, že až 80 \% nájdených mečov v Európe pochádza z vodných plôch. Tiež je dôležité uviest' fakt, že v neskorom stredoveku boli meče v rámci koryta Temže pri Londýne deponované hlavne pri Westminsteri a the City, kde boli samozrejme prítomní i obyvatelia mesta s vyšším spoločenským statusom. Naproti tomu boli dýky deponované po celej dížke Temže v rámci stredovekého Londýna (Clark 2013, 14-15, obrázok na s. 15).

Zo Západnej Európy vieme zase o románskych bronzových miskách, často zdobených alegóriami cností a nerestí, ktoré sa používali v kláštoroch aj na očist'ovanie sa pri pokání pred spoved’ou. Tie sa mali od 12. storočia podl'a nových výnosov odpustenia po splnení svojej úlohy zakopávat' alebo potápat' v rieke (Schulze 1984, 225). Bronzové misky, či už boli nejako zdobené alebo nie, nachádzame aj v nálezových kontextoch spojených s vodou od pomedzia Nemecka a Francúzska až po Rusko a oblast' Škandinávie v období 11. až 13. storočia (Scholz 2007, 249-250, poznámka č. 24).

Ďalšie vodné nálezy by mohli súvisiet' s uzmierovaním si vodných duchov, bohov alebo vodníkov. V databáze posudzovaných nálezov máme i bronzový štítkový prsteň z Váhu pri Trenčíne-Záblatí (pravdepodobne zo 14.-16. storočia), ktorý s týmito praktikami mohol tiež súvisiet'. V novoveku sa v Nemecku vhadzovali zlaté prstene každoročne do Walchensee (Bavorské Alpy, Nemecko) a Ammersee (juhozápadne od Mníchova v Nemecku) na uzmierenie vodných duchov či vodníkov. Takisto boli roku 1641 hodené do Bautopf v meste Blaubeuren (Švábsko, južné Nemecko) dva pozlátené strieborné poháre na uzmierenie si vodníkov (Schulze 1984, 229).

Dokonca $\mathrm{v}$ rámci Európy môžeme spomenút' napríklad dve dobre skúmané rieky s posvätnou kontinuitou, z ktorých evidujeme nálezy zbraní a iných artefaktov vo vel'mi dlhých časových úsekoch. Prvou riekou je rieka Ljubljanica (Slovinsko) s kontinuitou deponovania nálezov od

\footnotetext{
26 Lokalita Hlohovec; Kočovce.

27 Lokalita Dlhá nad Váhom; Neded - rameno Váhu v obci; Neded - koryto Váhu na 37.-38. riečnomkm; Nová Ves nad Váhom - Poličko; Šal'a - koryto Váhu na 55.-59. riečnom km; Šal'a-Veča - mítve rameno Váhu; Trnovec nad Váhom - koryto Váhu na 52. riečnomkm; Selice Váh na 43. riečnom km; Selice - koryto Váhu na 45.-47. riečnom km; Vlčany - koryto Váhu na 41. riečnomkm; Vodné dielo Selice. 28 Lokalita Drahovce; Koplotovce; Šala - koryto Váhu na 55.-59. riečnom km a možno i lokalita Dlhá nad Váhom.

29 Lokalita Trenčín - koryto Váhu; Trenčín - koryto Váhu pri moste na Ostrov; Trenčín-Orechové; Kostolná-Záriečie; Červeník; Sered' - Hrad Šintava; Šoporňa-Pasienok; Šoporňa-Štrkovec - Galantská sihot'; Dlhá nad Váhom (dve lokality); Horná Streda - Vážsky kanál; Moravany nad Váhom / Pieštany; Drahovce-Baková; Hlohovec; Sered' - Hrad Šintava (možno tri lokality); Šala - koryto Váhu na 56. riečnom km.
} 
mladšej doby kamennej do neskorého stredoveku (Gaspari 2003, 46, 51) a rieka Witham (Anglicko), kam sa ukladali nálezy od neskorej doby bronzovej do 14. storočia (Stocker-Everson 2003, $280,282,284)$. Je len otázne, či sem boli všetky predmety deponované kvôli uzmierovaniu si nejakých entít alebo aj kvôli ich zbavovaniu sa po splnení svojho účelu.

Vzt’ah krest’anstva a krest’anov k vode a vodným plochám v preberanom období bol rôzny a ako sme už naznačili vyššie pri románskych bronzových miskách, záležalo na tom, či voda alebo vodná plocha pomáhala spáse, bola miestom dejín spásy alebo či bola súčast’ou krest’anských náboženských úkonov, alebo spáse bránila pre povery a vykonávanie pohanských náboženských praktík. Brehy babylonských riek boli podl'a Knihy žalmov pre zajatých Židov miestom, kde smútili a spomínali na svoju vlast'. Preto na vŕby (spájajúce sa s vodou a vlhkými pôdami) tejto krajiny vešali svoje citary (Ž 137, 1-2). V Evanjeliu podl’a Jána sa dozvedáme, že už pravdepodobne pred verejným vystúpením Ježiša Krista a istotne počas neho existoval v Jeruzaleme pri Ovčej bráne rybník Betsata, ku ktorému chodili chorí, slepí, chromí a ochrnutí. Čakali, kým sa voda pohne, vtedy tam totiž zostupoval anjel, ktorý ju rozvíril. Kto do takto rozvírenej vody vošiel, bol uzdravený (Jn 5, 1-4).

V nasledujúcich veršoch Evanjelia podl’a Jána síce Ježiš uzdravil chromého aj bez jeho spustenia do rybníka Betsata, no v kapitole predtým Ježiš spomína jeho vlastnú vodu v nasledovnom výroku: „Ale kto sa napije z vody, ktorú mu ja dám, nebude žiznit’ naveky. A voda, ktorú mu dám, stane sa v ňom prameňom vody prúdiacej do večného života.“ (Jn 4, 14) Tiež v Zjavení apoštola Jána sa uvádza: „(...) lebo Baránok, čo je v strede pred trónom, bude ich pást’ a privedie ich k prameňom vôd života. “ (Zjv 7, 17) Cirkev spája s vodou i sviatost' krstu, pri obrade ktorého sa človek ponára do vody alebo sa mu leje voda na jeho hlavu a pri tom sa vzýva Najsvätejšia Trojica. Krstom sa odpúšt’a dedičný hriech, všetky osobné hriechy a všetky tresty za hriechy (KKC 1278; Vragaš ed. 2006, 345-346).

Božia moc je prítomná i v relikviách svätých, ${ }^{30}$ a tak, ked' boli podl'a Bedu Venerabilisa (673-735) kosti sv. Oswalda umyté pravdepodobne v rieke Witham a takto posvätili jej vody, voda okamžite získala silu liečit'. Vody Withamu boli odvtedy spájané s daným svätým skôr než s akýmikol'vek duchmi, ktorých doménou mohla byt' daná rieka predtým (Stocker-Everson 2003, 282). Nazdávame sa, že daná rieka získala podobným spôsobom liečivú silu ako vyššie uvedený rybník Betsata z Evanjelia podl’a Jána.

Cirkev a krest’anskí panovníci Európy prijímali viacero opatrení proti pohanskému uctievaniu vôd a vykonávaniu obiet vo vzt’ahu k vodám už od začiatku stredoveku. Dané pohanské praktiky sa do určitej miery museli konat' na území strednej Európy aj v období vrcholného a neskorého stredoveku. O tom máme niekol'ko zmienok, ktoré jeden zo spoluautorov tohto článku uviedol už vo svojich dvoch samostatných štúdiách. Týkajú sa predpisov Synody v Szabolcsi (20. mája 1092) v rámci Uhorského král'ovstva, zmienok kronikára Kosmasa (cca 1045-1125), textu Opatovického homiliára (České královstvo) z 11. a 12. storočia a krížovej výpravy z roku 1331 do okolia Cavoreta (dnešný Kobarid v západnom Slovinsku) pod vedením františkánskeho inkvizítora Franciscusa de Clugiu (Husár 2016, 16-17; 2016a, 136, 138).

\section{Záver}

V príspevku sme sa (hlavne) pomocou konfrontácie písomných a archeologických prameňov dotkli územia stredného a dolného toku Váhu v období od druhej polovice 11. do prvej polovice 16. storočia. Z nášho výskumu vyplynulo, že na nami skúmanom území, cez ktoré prechádzali Považská i Česká cesta, boli vo vrcholnom a neskorom stredoveku tri kategórie prechodov cez rieku Váh - brody (lat. vada), prievozy (lat. pontones) a mosty (lat. pontes). Ku nim treba ešte pripočítat' mýta (lat. telonea), ktoré mohli súvisiet' minimálne s jednou už vyššie spomenutou kategóriou prechodov. $\mathrm{S}$ istotou však s prechodmi nemôžeme rátat' v prípade prístavov (lat. portus).

$30 \mathrm{~V}$ kontexte paragrafu 828 Katechizmu katolíckej cirkvi (KKC 828). 
Vo vrcholnom stredoveku (druhá polovica 11. storočia až 13. storočie; obr. 1, 3) môžu nepriamo vodné nálezy z pril'ahlého koryta Váhu potvrdzovat' existenciu mýt v Hlohovci, Šali, Šintave, prievozu v Hlohovci/Červeníku a taktiež mostov v Hlohovci, Šali, Šintave a Trenčíne. Naopak, vodné nálezy vrcholného stredoveku absentujú v súvislosti s vtedajším mýtom v Banke a pravdepodobne i v Komárne.

Vrcholnostredoveké vodné nálezy z Váhu dokladajú existenciu prechodov, ktoré sa v písomných prameňoch spomínajú až v neskorom stredoveku. Ide konkrétne o mýta v Kočovciach, Kostolnej-Záriečí, Novej Vsi nad Váhom, Piešt’anoch a Trenčíne, brod v Hlohovci i Piešt’anoch a most v Šintave.

Pre obdobie neskorého stredoveku (14. storočie až prvá polovica 16. storočia; obr. 2, 4) môžeme vodné nálezy z Váhu korelovat' s blízkym mýtom v Hlohovci, Šali, Šintave, Trenčíne, Kočovciach, Piešt’anoch a Pintekovej Vsi (prostredníctvom protil'ahlých Dvorníkov-Červeníkov a Dvorníkov-Posádky alebo Bereku), potom s brodom v Ducovom (prostredníctvom blízkej Hubiny-Závažia), Hlohovci, Pieštanoch a Pintekovej Vsi (prostredníctvom protil’ahlých Dvorníkov-Červeníkov a Dvorníkov-Posádky alebo Bereku), prievozom v Hlohovci/Červeníku a s mostom v Hlohovci, Šintave/Seredi, Šali a Trenčíne. Absenciu vodných nálezov môžeme uviest' v spojitosti s mýtom a prievozom v Novom Meste nad Váhom ${ }^{31}$ a prievozom v Hrádku.

Na druhej strane sa nepodarilo doložit' v písomných prameňoch prechody cez Váh, ktoré súvisia s vrcholno- a neskorostredovekými vodnými nálezmi z lokality Trenčín-Záblatie (bronzový štítkový prsteň, len neskorý stredovek), z troch lokalít blízko Hornej Stredy (zbrane), dvoch lokalít blízko Drahoviec (zbrane, v prípade Drahoviec-Bakovej ide len o obdobie neskorého stredoveku), lokality Koplotovce (zbraň, len neskorý stredovek), dvoch lokalít blízko Šoporne (zbrane), dvoch lokalít blízko Dlhej nad Váhom (zbrane a keramika, len vrcholný stredovek), z lokality Král’ová nad Váhom (zbraň), z lokality blízko Trnovca nad Váhom (keramika, len vrcholný stredovek), z dvoch lokalít blízko Nededu (keramika), troch lokalít blízko Selíc (keramika, ostroha) a z lokality blízko Vlčian (keramika, kachlica). Z daného výpočtu jasne vidno, že v okolí Šale sa skladali vodné nálezy najmä z artefaktov, ktoré mohli súvisiet' skôr s obchodom alebo boli dokladom o odplavení (keramika), či boli skôr intencionálne deponované (zbrane). Proti prúdu Váhu, od Šale na sever, sú to predmety skôr v rámcoch intencionálneho deponovania (zbrane, šperky) a po prúde Váhu, na juh od Šale, zase predmety súvisiace skôr s dopravou, obchodom alebo odplavením (ostroha, kachlica, keramika).

Pri zhodnotení celého skúmaného územia sa dá tiež konštatovat', že vodné nálezy boli na sever od Šale a jej okolia vo vrcholnom i neskorom stredoveku skoro výhradne zbraňami (väčšinou na bodno-sečnými), pričom ostatné vodné nálezy predstavovala v prípade jednej lokality keramika, prsteň a minca a v prípade dvoch iných lokalít išlo o medené koláče. $Z$ toho vyplýva, že na danom úseku Váhu pravdepodobne prevažovali skôr nálezy deponované intencionálne. Od Šale až po Neded evidujeme v rámci vodných nálezov predmety s rôznorodou skladbou, popri už spomenutých zbraniach je tu zastúpená významne i keramika, d’alej sa tu našli aj podkovy a ostrohy. To naznačuje miesta súvisiace skôr s dopravou, obchodom alebo odplavením, ako sme uviedli už vyššie. Danú situáciu však môžeme vysvetlit’ aj súčasným stavom bádania Váhu, kedy sa častejšie, dlhodobejšie a precíznejšie skúmalo za pomoci amatérskych archeológov iba jeho územie v rámci okresu Šal'a. Od Nededu po Komárno nám, žial', absentujú relevantné dáta týkajúce sa vodných nálezov z pertraktovaného obdobia.

Aj ked' vodné nálezy na posudzovanom úseku Váhu nevieme vždy jasne priradit' k dôkazom o doprave, obchode, intencionálnom deponovaní atd', môžeme konštatovat', že na konkrétnom mieste museli prebiehat' minimálne určité presuny za nejakým účelom. Ako sme spomenuli už vyššie, presný obraz o tej-ktorej lokalite mat' nikdy nebudeme, čo dost' výrazne, samozrejme, ovplyvňuje samotný charakter vodného nálezu. Je však zaujímavé, že z priestoru prechodu Váhu medzi Sered’ou a Šintavou (priesečníka Považskej a Českej cesty) máme iba vodné nálezy vrcholno-/neskorostredovekých mečov. Z okolia Trenčína pochádzajú tiež len vrcholno-/

31 Ak nepočítame vrcholno- a neskorostredoveké vodné nálezy z protilahlých Kočoviec za Váhom. 
neskorostredoveké meče, ako aj neskorostredoveký prsteň i hrot kopije/oštepu. Rôznorodá skladba vodných nálezov pochádza z koryta Váhu pri Šali. Z vody sa na povrch odtial'to dostali nálezy zbraní, keramiky, súčastí odevu, nástrojov, zámku, súčastí konského postroja a výstroja jazdca. Takáto rôznorodá skladba nálezov môže súvisiet' hlavne s už spomínaným dlhodobým skúmaním okolia Šale, dôležitého bodu pri prekračovaní rieky Váh. Význam obchodných trás prechádzajúcich cez Váh pri Hlohovci / Červeníku a Novom Meste nad Váhom / Kočovciach dobre ilustrujú nálezy medených koláčov (z Hlohovca a Kočoviec), ktoré je možné datovat' do vrcholného i neskorého stredoveku.

\section{Pod'akovanie}

Touto formou chcú autori článku pod’akovat' nasledovným kolegom archeológom, ktorí im poskytli cenné informácie a literatúru k niektorým lokalitám spomenutým v článku: Mgr. Andásovi Csuthymu, PhD. (Podunajské múzeum v Komárne), Mgr. Jozefovi Urminskému (Vlastivedné múzeum v Hlohovci), Mgr. Petrovi Novosedlíkovi (Vlastivedné múzeum v Hlohovci), Mgr. Petrovi Schreiberovi (Trenčianske múzeum v Trenčíne), Jánovi Kormošimu (Archeologický krúžok Centra vol’ného času Tip Top v Šali). Taktiež d’akujeme vedeniu Archeologického ústavu Slovenskej akadémie vied, najmä jeho riaditel'ovi doc. PhDr. Matejovi Ruttkayovi, CSc., za poskytnutie prístupu k nálezovým správam spomenutým v zozname literatúry.

Tento článok bol vypracovaný v rámci projektov VEGA č. 1/0040/18 Stredoveké historické cesty na juhozápadnom Slovensku v kontexte stredoeurópskej dopravnej siete a ich odkaz pre súčasnost' a KEGA č. 004UKF-4/2018 Európsky stredovek interaktívne.

\section{Pramene a literatúra}

ARCANUM KÉZIKÖNYVTÁR: Arcanum Kézikönyvtár. Dostupné z: https://www.arcanum.hu/hu/online-kiadvanyok, cit. 26. 2. 2019.

ALEKSIĆ, M., 2007: Medieval Swords from Southeastern Europe. Material from 12th to 15th Century. Belgrade.

ANDERS, J.-GRINGMUTH-DALLMER, E., 2015: Gewässerfunde als Zeugnisse für das Alltagsleben am Fluss. In: O rzece i wodzie w życiu codziennym człowieka średniowiecza. Spotkania Bytomskie. Vol. VIII (Moździoch, S.-Chrzan, K., edd.), 13-27. Wrocław.

BAXA, P., 1981: Podkúvanie na Slovensku v 11.-13. storočí, SlArch XXIX, 425-443.

BIALEKOVÁ, D., ed., 1989: Pramene k dejinám osídlenia Slovenska z konca 5. až z 13. storočia. 1. zväzok. 1. čast'. Bratislava - Nitra.

BIALEKOVÁ, D., ed., 1989a: Pramene k dejinám osídlenia Slovenska z konca 5. až z 13. storočia. 1. zväzok. 2. čast'. Bratislava - Nitra.

BISHOP, M. C.-COULSTON, J. C. N., 2006: Roman Military Equipment. From the Punic Wars to the Fall of Rome. Oxford.

BRANCSIK, K., 1914: Über die Ergebnisse unserer Grabungen wie auch über prähistorische Zufallsfunde im Comitate, Trencsén vármegyei múzeum-egyesület értesitöje, 22-36.

CDAC VI: Codex diplomaticus Arpadianus continuatus VI (Wenzel, G., ed.). Pest 1867.

CDAC X: Codex diplomaticus Arpadianus continuatus X (Wenzel, G., ed.). Pest 1873.

CDH VII/2: Codex diplomaticus Hungariae VII/2 (Fejér, G., ed.). Budae 1832.

CDP VII: Codex diplomaticus Patrius VII (Nagy, I., ed.). Budapestini 1880.

CDS1 II: Codex diplomaticus et epistolaris Slovaciae II (Marsina, R., ed.). Bratislava 1987.

CLARK, J., 2013: Medieval finds from the River hames: accidental loss, rubbish or ritual? Prednáška. Museum of London. London.

CLARK, J., ed., 1995: The Medieval Horse and Its Equipment, c. 1150 - c. 1450. Medieval Finds from Excavations in London 5. London.

DOSTÁL, B., 1966: Slovanská pohřebiště ze střední doby hradištní na Moravě. Praha. 
DZURO, D., 2017: Rieka Váh ako dopravný koridor v stredoveku, Balneologický spravodajca 2015-2017, Vlastivedný zborník múzea, 82-122.

ЂУРОВИЋ, И., 2012: Средњовековни накит : из збирки Народног музеја Крагујевац. Крагујевац.

EGGERT, M. K. H.-SAMIDA, S., 2013: Ur- und Frühgeschichtliche Archäologie. 2. überarbeitete und aktualisierte Auflage. Tübingen und Basel.

FRIDRICHOVÁ, D., 2017: Mestské brány a ich napojenie na cestnú siet’ v stredoveku. In: Dejiny cestnej dopravy na Slovensku II, 69-82. Žilina.

FRS IV: Fontes rerum Slovacarum IV. Archivum familiae Očkaj. Stredoveké dejiny rodiny Očkajovcov a listiny z jej archívu (Marek, M., ed.). Kraków - Trnava 2015.

GÁLIK, Z., 2016: Mikuláš Kont a jeho hradné panstvo Hlohovec. Historia Nova: Priezory do dejín 11, 8-32. Dostupné z: https://fphil.uniba.sk/fileadmin/fif/katedry_pracoviska/ksd/h/Hino11.pdf, cit. 18. 9. 2018.

GASPARI, A., 2003: Archaeology of the Ljubljanica River (Slovenia): early underwater investigations and some current issues, The International Journal of Nautical Archaeology 32, č. 1, 42-52. https://doi.org/10.1111/j.1095-9270.2003.tb01430.x

GŁOSEK, M., 1984: Miecze środkowoeuropejskie z X-XV w. Warszawa.

- 1996: Późnośredniowieczna broń obuchowa w zbiorach polskich. Warszawa - Łódź.

GUDEA, N., 2010: Beiträge zur Kenntnis des spätrömischen Heers (4. Jahrhundert). 1. Waffen für Fernkampf aus den Wehranlagen an der Nordgrenze von Dacia Ripensis, Revista Bistriţei XXIV, $267-284$.

HEINDEL, I., 1992: Äxte des 8. bis 14. Jahrhunderts im westslawischen Siedlungsgebiet zwischen Elbe/ Saale und Oder/Neisse, Zeitschrift für Archäologie 26, č. 1, 17-56.

HLAVAČKOVÁ, M., 2010: Komárno. In: Štefánik, M.-Lukačka, J. a kol., Lexikon stredovekých miest na Slovensku, 183-193. Bratislava.

HISTÓRIA MESTSKEJ ČASTI VEČA 2016: História mestskej časti Veča 2016. Dostupné z: https://sala.sk/ clanok/historia-mestskej-casti-veca, cit. 18. 9. 2018.

HOKL: Hazai oklevéltár 1234-1536 (Nagy, I.-Deák, F.-Nagy, G., edd.). Budapest 1879.

HRUBEC, I., 1980: Povel'komoravské obdobie a stredovek, SlArch XXVIII, 229-237.

HRUBÝ, T., 2015: Osídlenie Dolného Považia v stredoveku. Príspevok k dejinám sídelného vývoja Západného Slovenska. Kraków - Trnava.

HUSA, V.-PETRÁŇ, J.-ŠUBRTOVÁ, A., 1967: Homo faber: Pracovní motivy ve starých vyobrazení. Praha.

HUSÁR, M., 2014: Žrd’ovo-bodné zbrane včasného stredoveku v Karpatskej kotline. 1. diel. Typológia a jej vyhodnotenie. Nitra.

- 2016: Finds of the Early Medieval Thrusting Pole Arms from Watery Locations of the Carpathian Basin, Acta Militaria Mediaevalia XII, 7-23.

- 2016a: Vodné nálezy včasnostredovekých hrotov oštepov a kopijí z Karpatskej Kotliny, Musaica archaeologica 1/2, 127-146.

- 2017: Prelom antiky a stredoveku na území Macedónskej republiky na príklade žrd’ovo-bodných zbraní. In: Byzantinoslovaca VI. Zborník k nedožitému životnému jubileu Alexandra Avenaria (Daniš, M.-Hurbanič, M.-Zervan, V., edd.), 114-128. Bratislava.

CHRASTINA, P.-RÁCOVÁ, K., 2015: Mosty na území Nitrianskej stolice v prvej polovici 18. storočia podla Notícií Mateja Bela (historicko-geografický prístup), Studia historica Nitriensia 19, č. 1, 20-36.

CHRASTINA, P.-RÁCOVÁ, K.-BRŮNA, V., 2015: Bridges over the Váh River in the territory of the Nitra County in the first half of 18th century (according to Notitia Hungariae historico-geographica by Matthias Bel), Revista Transilvania 8, č. 6-7, 79-86.

IMHOF, U. K., 2010: Die Geschichte des Hufbeschlags, Schweizer Archiv für Tierheilkunde 152, 21-29.

IVANIČ, P., 2017: Cestné mýto na dolnom a strednom Považí v stredoveku. In: Dejiny cestnej dopravy na Slovensku II, 59-68. Žilina.

JANKÓ, A.-PORUBSKÁ, B., 2013: Vojenské mapovanie na Slovensku, 1769-1883. Bratislava.

JN, 2011: Evanjelium podl’a Jána. In: Sväté písmo Starého i Nového zákona, 1390-1418. Trnava.

ЙОТОВ, В., 2004: Въоръжението и снаряжението от българското средновековие (VII-XI век). Варна.

DIE JOSEPHINISCHE LANDESAUFNAHME 1782-1785: Königreich Ungarn. Dostupné z: https://mapire.eu/en/synchron/firstsurvey-hungary/, cit. 18. 9. 2018.

KALMÁR, J., 1971: Régi magyar fegyverek. Budapest.

KARLÍK, M., 2013: Trenčianske mosty vel’akrát ničili rozsiahle povodne a l’ad. Dostupné z: http://nastrencin.sme.sk/c/6774951/trencianske-mosty-velakrat-nicili-rozsiahle-povodne-alad.html, cit. 12. 9. 2018.

KATKIN, S., 1996: Fragment železného meča zo Šoporne, Archeologické výskumy a nálezy na Slovensku 1994, 106, obr. 73 . 
КИРПИЧНИКОВ, А. Н., 1966: Древнерусское оружие. Выпуск второй. Копья, сулицы, боевые топоры, булавы, кистени IX-XIII вв. Москва - Ленинград.

KIRPIČNIKOV, A. N., 1986: Russische Waffen des 9.-15. Jahrhunderts, Waffen und Kostümkunde 28, č. 2, 85-129.

KKC, 2017: Katechizmus katolíckej cirkvi. Trnava.

KLČO, M., 1988: Stredoveká železná sekera z Moravian nad Váhom - Hubiny, Archeologické výskumy a nálezy na Slovensku 1987, 76, obr. 16.

- 1991: Stredoveká železná sekera z Drahoviec, Archeologické výskumy a nálezy na Slovensku 1989, 50, obr. 14.

- 2004: Nové nálezy militárií z Drahoviec, Balneologický spravodajca XXXVIII, 194-199.

- 2011: Kord zo zbierok Balneologického múzea v Piešt’anoch, Balneologický spravodajca XL (2008-2010), 345-347.

KLČO, M.-KRUPA, V., 1991: Chladné zbrane zo zbierok Balneologického múzea v Pieštanoch. I. Tesáky, Balneologický spravodajca XXX, 27-31.

- 1993-1994: Chladné zbrane zo zbierok Balneologického múzea v Piešt’anoch. II. Meče, Balneologický spravodajca XXXII, 139-145.

- 1994: Katalóg zbraní zo zbierok Balneologického múzea v Piešt’anoch. Pieštany.

- 2004: Stredoveké zbrane v zbierkach Balneologického múzea v Piešt’anoch. In: Zbrane a zbroj. Zborník príspevkov zo sympózia usporiadaného pri príležitosti výstavy Zbrane a zbroj (Malečková, K., ed.), 37-52. Bojnice.

KLIMEK, T., 2014: Krajiny českého středověku. Praha.

KNAUZ, N., 1882: Monumenta ecclesiae Strigoniensis II. Strigonii.

KNIFIC, T.-NABERGOJ, T., 2017: Medieval Stories from the Crossroads. Ljubljana.

KOSMAS, 2011: Kronika Čechů. Praha.

KOÓŠOVÁ, P., 2004: Ku klasifikácii vrcholnostredovekých ostrôh z územia Slovenska (12.-15. storočie) Zur Klassifikation der hochnmittelalterlichen Sporen auf dem Gebiet der Slowakei (12.-15. Jahrhundert), AH 29, 523-547.

- 2007: Ku klasifikácii neskorostredovekých a včasnonovovekých ostrôh z územia Slovenska, Zborník Filozofickej fakulty Univerzity Komenského - Musaica XXV, 257-276.

KOTOWICZ, P. N., 2014: Topory wczesnośredniowieczne z ziem polskich. Katalog źródeł. Rzeszów.

KOVÁCS, T. S., 2016: Maces, War-Hammers and Topors from Hungarian Collections. Budapest.

LEHOTSKÁ, D., 1956: Archív mesta Bratislavy: inventár stredovekých listín, listov a iných príbuzných písomností. Praha.

LUKAČKA, J., 1993-1994: Piešt’any v stredoveku, Balneologický spravodajca XXXII, 100-109.

- 2010: Hlohovec. In: Štefánik, M.-Lukačka, J. a kol., Lexikon stredovekých miest na Slovensku, 164-168. Bratislava.

LABUDA, M., 2016: Chladné zbrane 10.-16. storočia pochádzajúce z rieky Váh. Magisterská diplomová práca, ulož. v ÚAM FF MU, Brno.

MÁDL, J., 1936: Nález medených platní v Kočovciach, Sborník Muzeálnej slovenskej spoločnosti 30, 110-111.

MNL OL DF: Magyar Nemzeti Levéltár, Országos Levéltár, Budapest, Diplomatikai Fényképgyüjtemény.

MNL OL DL: Magyar Nemzeti Levéltár, Országos Levéltár, Budapest, Diplomatikai Levéltár.

MÁJ 2003 PRI PRÍLEŽITOSTI 890. VÝROČIA: Máj 2003 pri príležitosti 890. výročia, bol slávnostne odhalený a posvätený ERB a PEČAŤ Mestskej časti Veča. Dostupné z: https:/veca8.webnode.sk/products/ symboly-mestskej-casti-sala-veca/, cit. 18. 9. 2018.

MAREK, L., 2008: Broń biała na Śląsku XIV-XVI wiek. Wratislavia Antiqua 10. Wrocław.

MARSINA, R., 2010: Trenčín. In: Štefánik, M.-Lukačka, J. a kol., Lexikon stredovekých miest na Slovensku, 511-522. Bratislava.

MARSINA, R.-KUŠÍK, M., 1959: Urbáre feudálnych panstiev na Slovensku 1. (16. storočie). Bratislava.

MICHALAK, A., 2012: Broń w wodnej toni. Uwagi o akwatycznych znaleziskach broni późnośredniowiecznej, na marginesieodkryć z Lutola Mokrego. In: Woda - żywioł ujarzmiony i nieujarzmiony (Jaszewska, A.-Michalak, A., edd.), 289-314. Zielona Góra.

MÚČKA, V.-DANIŠ, M.-ŠEVČÍKOVÁ, Z., 2006: Dejiny európskeho stredoveku. I. raný stredovek (od 5. storočia do polovice 11. storočia). Prešov.

NADOLSKI, A., 1954: Studia nad uzbrojeniem polskim w X, XI a XII wieku. Acta archaeologica Universitatis Lodziensis 3. Łódź. 
NÁLEZOVÁ SPRÁVA AÚ SAV č. 601/55, 1955: Nálezová správa Archeologického ústavu Slovenskej akadémie vied č. 601/55.

NÁLEZOVÁ SPRÁVA AÚ SAV č. 1468/63, 1963: Nálezová správa Archeologického ústavu Slovenskej akadémie vied č. 1468/63.

NÁLEZOVÁ SPRÁVA AÚ SAV č. 3926/67, 1967: Nálezová správa Archeologického ústavu Slovenskej akadémie vied č. 3926/67.

NÁLEZOVÁ SPRÁVA AÚ SAV č. 5181/70, 1970: Nálezová správa Archeologického ústavu Slovenskej akadémie vied č. 5181/70.

NIȚOI, A., 2007: Arme şi armuri în colecţiile Muzeului Brukenthal. Brukenthal.

NOVOSEDLÍK, P., 2002: Nález stredovekého meča v Hlohovci, Archeologické výskumy a nálezy na Slovensku 2001. 1. textová čast', 2. obrázková čast', 143, obr. 103.

- 2002a: Nález medeného koláča v Hlohovci, Archeologické výskumy a nálezy na Slovensku 2001. 1. textová čast', 2. obrázková čast', 143-144, obr. 104.

- 2004: Medený koláč z Hlohovca, Slovenská numizmatika 17, 253-256

NOVOTNÝ, B., 1956: Tausované sekerky z Čech, Památky archeologické XLVII, 335-347.

- 1965: Nález železných predmetov v Nitre, Sborník Filozofickej fakulty Univerzity Komenského - Musaica XVI (V), 69-79.

OAKESHOTT, E., 2000: Records of the Medieval Sword. Woodbridge.

OBČIANSKE ZDRUŽENIE VODNÝ HRAD - záchrana seredského kaštiela, bývalého vodného hradu Šintava, História vodného hradu, Mapy. Dostupné z: http://www.vodnyhrad.sk/historia-vodneho-hradu/ mapy, cit. 21. 1. 2019.

PETRENKO, V. G., 1995: Scythian Culture in the North Caucasus. In: Nomads of the European Steppes in the Early Iron Age (Davis-Kimball, J.-Bashilov, V. A.-Yablonsky, L. T., edd.), 6-25. Berkeley.

PIŠÚT, P.-PROCHÁZKA, J.-MATEČNÝ, I.-BANDURA P., 2016: Vývoj koryta Váhu pri Leopoldove v 17.-20. storočí a odozva rieky na zásahy človeka. Bratislava.

PLAČEK, M.-BÓNA, M., 2007: Encyklopédia slovenských hradov. Bratislava.

PODBORSKÝ, V., 2012: Úvod do studia archeologie. Brno.

POZDIŠOVSKÝ, Š., 1956: Váh vydáva svoje poklady, Informačné zprávy Okresného múzea v Trenčíne 8, $11-12$.

PSZBRT II: A Pannonhalmi Szent-Benedek-Rend története II (Erdélyi, L., ed.). Budapest 1903.

RDSI I: Regesta diplomatica nec non epistolaria Slovaciae I (Sedlák, V., ed.). Bratislava 1980.

RDSI II: Regesta diplomatica nec non epistolaria Slovaciae II (Sedlák, V., ed.). Bratislava 1987.

RRSA II: Regesta regum stirpis Arpadianae critico-diplomatica. Tomus II (Szentpétery, I., ed.). Budapestini 1943.

RASL, Z., 1987: K typologii a konstrukci stř̌edověkých závěsných zámků. In: Zkoumání výrobních objektů a technologií archeologickými metodami, 146-165. Brno.

RUTTKAY, A., 1975: Waffen und Reiterausrüstung des 9. bis zur ersten Hälfte des 14. Jahrhunderts in der Slowakei (I), SlArch XXIII, 119-216.

- 1976: Waffen und Reiterausrüstung des 9. Bis zur ersten Hälfte des 14. Jahrhunderts in der Slowakei (II), SlArch XXIV, 245-395.

- 1978: Umenie kované v zbraniach. Bratislava.

- 1982: The Organization of Troops, Warfare and Arms in the Period of the Great Moravian State, SlArch XXX, 165-198.

- 1985: Ďalší hromadný nález stredovekých železných predmetov a sídliskové nálezy z Nového Tekova, Archeologické výskumy a nálezy na Slovensku 1984, 209-210.

SCHOLTZ, U., 2007: Überlegungen zu den früh- und hochmittelalterlichen Gewässerfunden in Bayern, Acta praehistorica et archaelogica 39, 245-269.

SCHULZE, M., 1984: Diskussionsbeitrag zur Interpretation früh- und hochmittelalterlicher Flußfunde, Frühmittelalterliche Studien 18, 222-248. https://doi.org/10.1515/9783110242171.222

SERDON, V., 2005: Armes du diable: Arcs et erbaletes au Moyen Age. Rennes.

SLAVKOVSKÝ, P., 2014: S nošou za industrializáciou krajiny. Bratislava.

SLOVENSKÉ HRADY: Slovenské hrady - obrazy a pohlednice od různých autorů, Trenčín - panorama města z let 1550-75. Dostupné z: https://www.hrady-zriceniny.cz/img/stare4/ruzne_SK/trencin_panorama_mesta_z_let_1550-75.jpg, cit. 18.9. 2018.

STAVY A PRIETOKY NA VODNÝCH TOKOCH: Dostupné z: http://www.povodia.sk/ozpn/sap/sk/index. htm. http://www.povodia.sk/dunaj/sk/index.htm, cit. 3. 2. 2019. 
STOCKER, D.-EVERSON, P., 2003: The Straight and Narrow Way: Fenland Causeways and the Conversion of the Landscape in the Witham Valley. Lincolnshire. In: The Cross Goes North: Processes of Conversion in Northern Europe, AD 300-1300 (Carver, M., ed.), 271-288. Woodbridge.

STRZYŻ, P., 2006: Uzbrojenie we wczesnośredniowiecznej Małopolsce. Łódź.

SZÜCSI, F., 2013-2014: Avar kori balták, bárdok, szekercék és fokosok. Baltafélék a 6-8. századi Kárpát-medencében, Alba Regia 42, 113-186.

ŠEDIVÝ, J., 2014: Stredoveké prístavy (prievozy) a mýta na Dunaji v okolí Bratislavy. In: Na sútoku riek. Život v slovensko-rakúskom pohraničí, 343-370. Bratislava.

ТЕРСЬКИЙ, С. В., 2005: 3 історії української зброї XIII-XVIII ст.: сокири-бердиші та алебарди. In: Вісник Національного університету “Львівська політехніка" 528 - Держава та армія (Дещинський, Л. Є., еd.), 16-27. Львів.

ȚIPLIC, M. E. C., 2011: Weapons and Military Equipment Found in the German Settlement Area from Southern Transylvania (the 12th-13th Centuries). Some Aspects and Perspectives. In: Studia Universitatis Cibiniensis, Series Historica VIII, Supplementum 1. Proceedings of The 1st International Conference Interethnic Relations in Transylvania. Militaria Mediaevalia in Central and South Eastern Europe, Sibiu, October 14th-17th, 2010 (Ţiplic, I. M., ed.), 73-104. Sibiu.

TÓTH, A. J., 2009: The Queen Mary project - topographical survey in the Danube Band, Hungary. In: Jurišićev zbornik. Zbornik radova u znak sjećanja na Marija Jurišića (Bekić, L., ed.), 412-418. Zagreb.

TURČAN, V., 1999: Nálezy vybagrované z Dunaja, ZbSNM XCIII - Archeológia 9, 79-84.

URMINSKÝ, J., 1995: Stredoveké nálezy z Dvorník-Posádky, Archeologické výskumy a nálezy na Slovensku 1993, 132.

- 2003: Staré hlohovské mosty (čo prezrádzajú vo Váhu utopené staré drvené koly). Dostupné z: http:// historia.elap-hlohovec.sk/publikacna-cinnost.html?id=118, cit. 18. 9. 2018.

- 2018: Ked' Váh otvorí trinástu komnatu, Fraštacké noviny, 31. január 2018. Dostupné z: http://www.frastackenoviny.sk/relax/1966-muzeum, cit. 12. 6. 2019.

- 2019: Vylovené z rieky. Príbehy archeologických riečnych objavov v Hlohovci a okolí. Výstava Vlastivedného múzea v Hlohovci (20. 2. - 24. 3. 2019). Interný sprievodný text k výstave. Vlastivedné múzeum v Hlohovci. Hlohovec.

VARSIK, B., 1965: Husitské revolučné hnutie a Slovensko. Bratislava.

- 1990: Slovanské (slovenské) názvy riek na Slovensku a ich prevzatie Mad’armi v 10.-12. storočí (Príspevok k etnogenéze Slovákov). Bratislava.

VENDTOVÁ, V., 1964: Prehl'ad slovanských lokalít v Pobedime a okolí, ŠZ AÚ SAV 14, 161-174.

VÍCH, D., 2016: Relikty zaniklých cest mezi Křenovem a Hradcem nad Svitavou na Svitavsku ve světle archeologických nálezů, AVČ 12, 56-75.

VOZÁK, Z.-KORMOŠI, J., 2013: Okres Šal’a. Archeologické nálezy a náleziská. Archeologický krúžok Centra vol'ného času. Šal'a. Nepublikované.

VRAGAŠ, Š., ed., 2006: Teologický a náboženský slovník. I. diel. A-K. Trnava.

WEISZ, B., 2013: A királyketteje és az ispán harmada. Vámok és vámszedés Magyarországon a középkor első felében. Budapest.

WENZEL, G., 1874: Stibor vajda. Életrajzi tanulmány. Budapest.

ZÁBOJNÍK, J., 2010: Problematika včasného stredoveku na Slovensku, HČ 58, 213-231.

ZÁSADY OCHRANY PZ HLOHOVEC: Pamiatková zóna Hlohovec. Zásady ochrany pamiatkového územia - aktualizácia, Veduty, 15. júla 2014. Dostupné z: https://www.pamiatky.sk/Content/PZ_ZASADY/ Hlohovec/0209-Hlo-veduty.pdf, cit. 22. 1. 2019.

ZJV, 2011: Zjavenie apoštola Jána (Apokalypsa). In: Sväté písmo Starého i Nového zákona, 1594-1612. Trnava.

ZSO II/1: Zsigmondkori oklevéltár II. (1400-1410): Első rész (1400-1406) (Mályusz, E., ed.). Budapest 1956.

ZSO III: Zsigmondkori oklevéltár III. (1411-1412) (Mályusz, E.-Borsa, I., edd.). Budapest 1993.

ZSO VII: Zsigmondkori oklevéltár VII. (1419-1420) (Mályusz, E.-Borsa, I., edd.). Budapest 2000.

ZSO IX: Zsigmondkori oklevéltár IX. (1422) (Borsa, I.-Tóth, N., edd.). Budapest 2004.

Ž, 2011: Kniha žalmov. In: Sväté písmo Starého i Nového zákona, 633-733. Trnava.

ŽÁKOVSKÝ, P., 2008: Tauzované kopí se jménem Viktorina ze Žerotína. Př́íspěvek ke klasifikaci a datování hrotů kopí s částečně hraněnou tulejí, CB 11, 473-482.

- 2011: Středověké a raně novověké chladné zbraně ze sbírek Městského muzea v Moravském Krumlově. In: Hrad jako technický problém. Technologie a formy výstavby středověkých opevněných sídel (Měř́nský, Z., ed.), 127-188. Brno. 
- 2014: Tesáky a problematika jednosečných zbraní středověku a raného novověku. Disertační práce, ulož. v ÚAM FF MU, Brno.

- 2014a: Tesáky a problematika jednosečných zbraní středověku a raného novověku. Disertační práce. Katalog jednosečných zbraní středověku a raného novověku z území Moravy a českého Slezska, ulož. v ÚAM FF MU, Brno.

- 2015: Středověká militaria z boleradického hradu. In: Boleradický hrad (Unger, J., ed.), 74-83. Brno.

\section{Zusammenfassung}

\section{Flussübergänge am Unter- und Mittellauf der Waag im Hoch- und Spätmittelalter im Kon- text von schriftlichen und materiellen Quellen}

Im vorliegenden Beitrag haben wir (überwiegend) anhand einer Konfrontation von schriftlichen und archäologischen Quellen das Gebiet des mittleren und unteren Flusslauf der Waag in der Zeit ab der zweiten Hälfte des 11. bis zur ersten Hälfte des 16. Jahrhunderts behandelt. Aus unserer Grabung hat sich ergeben, dass es in dem von uns untersuchten Gebiet, durch welches die Waagstraße und auch die Via Bohemica führten, im Hoch- und Spätmittelalter drei Kategorien Flussübergänge über die Waag gegeben hat - Furten (lat. vada), Fähren (lat. pontones) und Brücken (lat. pontes). Zu ihnen müssen noch Mautstellen (lat. telonea) gezählt werden, die mindestens mit einer der oben erwähnten Kategorie zusammenhängt. Im Falle von Häfen (lat. portus) können wir jedoch mit Bestimmtheit mit keinen Übergängen rechnen.

Im Hochmittelalter (zweite Hälfte 11. Jahrhundert bis 13. Jahrhundert; Abb. 1, 3) kann die Existenz von Mautstellen durch indirekte Wasserfunde aus dem Flussbett der Waag belegt werden bei Hlohovec, Šal'a, Šintava, der Fähre in Hlohovec/Červeník und auch bei den Brücken in Hlohovec, Šal'a, Šintava und Trenčín. Umgekehrt fehlen Wasserfunde aus dem Hochmittelalter im Zusammenhang mit der damaligen Mautstelle in Banka und wahrscheinlich auch in Komárno.

Hochmittelalterliche Wasserfunde aus der Waag belegen die Existenz von Flussübergängen, die erst im Spätmittelalter in den schriftlichen Quellen Erwähnung finden. Konkret handelt es sich dabei um die Mautstellen in Kočovce, Kostolná-Záriečie, Nová Ves nad Váhom, Pieštany, und Trenčín, um die Furt in Hlohovec und Pieštany und um die Brücke in Šintava.

Für die Zeit des Spätmittelalters (14. Jahrhundert bis erste Hälfte 16. Jahrhundert; Abb. 2, 4) können wir Wasserfunde aus der Waag mit den nahegelegenen Mautstellen in Hlohovec, Šal'a, Šintava, Trenčín, Kočovce, Piešt’any und Pintekova Ves (gegenüberliegende Gemeinden Dvorníky-Červeníky und Dvorníky-Posádka oder Berek) korrelieren, dann mit den Furten in Ducové (nahegelegene Fundstelle Hubina-Závažie), Hlohovec, Piešt'any und Pintekova Ves (gegenüberliegende Gemeinden Dvorníky-Červeníky und Dvorníky-Posádka oder Berek), den Fähren in Hlohovec/Červeník und den Brücken in Hlohovec, Šintava/Sered', Šal'a, und Trenčín. Das Fehlen von Wasserfunden können wir mit einer Mautstelle und einer Fähre in Nové Mesto nad Váhom (nicht eingezogen die hoch- und spätmittelalterlichen Wasserfunde aus der gegenüberliegenden Gemeinde Kočovce, hinter der Waag) und mit einer Fähre in Hrádok in Verbindung bringen.

Andererseits ist es nicht gelungen, in den schriftlichen Quellen Flussübergänge über die Waag zu belegen, die zusammenhängen mit hoch- und spätmittelalterlichen Wasserfunden von der Fundstelle Trenčín-Záblatie (Schildring aus Bronze, nur Spätmittelalter), von drei Fundstellen in der Nähe von Horná Streda (Waffen), von zwei Fundstellen in der Nähe von Drahovce (Waffen, bei Drahovce-Baková handelt es sich nur um die Zeit des Spätmittelalters), von der Fundstelle Koplotovce (Waffe, nur Spätmittelalter), von zwei Fundstellen in der Nähe von Šoporňa (Waffen), von zwei Fundstellen in der Nähe von Dlhá nad Váhom (Waffen und Keramik, nur Hochmittelalter), von der Fundstelle Král'ová nad Váhom (Waffe), von der Fundstelle in der Nähe von Trnovec nad Váhom (Keramik, nur Hochmittelalter), von zwei Fundstellen in der Nähe von Neded (Keramik), von drei Fundstellen in der Nähe von Selice (Keramik, Sporn) und von der Fundstelle in der Nähe von Vlčany (Keramik, Kachel). Aus der gegebenen Aufzählung 
wird ersichtlich, dass die Wasserfunde in der Umgebung von Šal’a hauptsächlich aus Artefakten bestehen, die eher mit dem Handel zusammenhängen konnten, bzw. weggeschwemmt (Keramik) oder eher absichtlich deponiert wurden (Waffen). Flussaufwärts von Šal'a nach Norden sind es eher Gegenstände im Rahmen einer absichtlichen Deponierung (Waffen, Schmuck), und flussabwärts südlich von Šal'a hingegen Gegenstände, die eher mit dem Verkehr und Handel zusammenhängen oder weggeschwemmt wurden (Sporn, Kachel, Keramik).

Bei der Auswertung der gesamten untersuchten Gebietes kann auch festgehalten werden, dass es sich bei den nördlich von Šal'a und dessen Umgebung gemachten Wasserfunden - sowohl bei den aus dem Hoch- als auch aus dem Spätmittelalter stammenden - fast ausschließlich um Waffen handelte (zumeist Hieb- und Stichwaffen), wobei die übrigen Wasserfunde bei einer Fundstelle Keramik, einen Ring und eine Münze und bei zwei anderen Fundstellen Kupferkuchen darstellten. Daraus ergibt sich, dass im betreffenden Abschnitt der Waag wahrscheinlich eher Funde überwogen, die absichtlich deponiert wurden. Von Šal'a bis Neded registrieren wir im Rahmen der Wasserfunde Gegenstände von unterschiedlicher Zusammensetzung, neben den bereits erwähnten Waffen ist hier auch Keramik in bedeutendem Maße vertreten, ferner fand man auch Hufeisen und Sporen. Wie bereits oben aufgeführt, deutet das auf Stellen hin, die eher mit Handel und Verkehr zusammenhängen oder weggeschwemmt wurden. Die gegebene Situation können wir jedoch auch mit dem gegenwärtigen Forschungsstand bzgl. der Waag erklären, da häufiger, langfristiger und genauer mit der Hilfe von Amateurarchäologen bloß ihr Gebiet im Rahmen des Bezirks Šal’a untersucht wurde. Von Neded bis Komárno fehlen uns leider relevante Daten bezüglich Wasserfunden aus dem hier behandelten Zeitraum.

Selbst wenn wir die im beurteilten Gebiet gemachten Wasserfunde nicht immer klar als Belege für Verkehr, Handel, absichtliche Deponierung usw. einordnen können, lässt sich festhalten, dass an der jeweils konkreten Stelle zumindest bestimmte Beförderungen zu irgendwelchen Zwecken stattgefunden haben müssen. Wie oben bereits erwähnt, werden wir nie ein genaues Bild von irgendeiner Fundstelle erhalten, was selbstverständlich durch den Charakter eines Wasserfundes selbst sehr stark beeinflusst wird. Es ist jedoch interessant, dass im Bereich des Flussübergangs über die Waag zwischen Sered' und Šintava (wo sich Waagstraße und Via Bohemica kreuzen) nur Wasserfunde in Form von hoch-/spätmittelalterlichen Schwertern gemacht wurden. Aus der Umgebung von Trenčín stammen ebenfalls nur hoch-/spätmittelalterliche Schwerter sowie ein spätmittelalterlicher Ring und die Spitze einer Lanze oder eines Speers.

Eine sehr unterschiedliche Zusammensetzung von Wasserfunden stammt aus dem Flussbett der Waag bei Šal'a. Dort kamen Funde von Waffen, Keramik, Kleidungsteilen, Werkzeugen, Schlössern, Pferdegeschirr und Reiterausstattungen an die Oberfläche. Eine solch verschiedenartige Zusammensetzung an Funden kann vor allem mit der bereits erwähnten langfristigen Untersuchung der Umgebung von Šal'a zusammenhängen, das einen wichtigen Punkt beim Überqueren der Waag darstellte. Die Bedeutung der die Waag überquerenden Handelstrassen bei Hlohovec/Červeník und Nové Mesto nad Váhom/ Kočovce wird gut durch die Kupferkuchenfunde (aus Hlohovec und Kočovce) illustriert, die in das Hoch- und auch ins Spätmittelalter datiert werden können.

Der vorliegende Beitrag wurde ausgearbeitet im Rahmen der Förderprojekte VEGA Nr. 1/0040/18 Mittelalterliche Wege in der Südwest-Slowakei im Kontext des mitteleuropäischen Verkehrsnetzes und ihr Vermächtnis für die Gegenwart sowie KEGA Nr. 004UKF-4/2018 Das europäische Mittelalter interaktiv. 
prof. PhDr. Peter Ivanič, PhD., Ústav pre výskum kultúrneho dedičstva Konštantína a Metoda Filozofickej fakulty Univerzity Konštantína Filozofa v Nitre, Štefánikova 67, 94974 Nitra, Slovenská republika, pivanic@ukf.sk

Mgr. Martin Husár, PhD., Ústav pre výskum kultúrneho dedičstva Konštantína a Metoda Filozofickej fakulty Univerzity Konštantína Filozofa v Nitre, Štefánikova 67, 94974 Nitra, Slovenská republika, mhusar@ukf.sk 
